RELAÇÕES ECONÔMICAS ENTRE CUSTO DE TRANSAÇÃO

DE UM BANCO PRIVADO E CRÉDITO RURAL

JÚLIO CESAR SILVA GUIDETTI

Engenheiro Agrônomo

Orientador: Prof. Dr. PAULO EERNANDO CIDADE DE ARAÚJO

Dissertação apresentada à
Escola Superior de Agricultura
"Luiz de Queiroz", Universidade
de São Paulo, para a obtenção
do titulo de Mestre em
Ciências, Área de Concentração:
Economia Aplicada.

Piracicaba

Estado de São Paulo - Brasil

Novembro - 1998 
Dados Internacionais de Catalogação na Publicação (CIP) DIVISĀO DE BIBLIOTECA E DOCUMENTAÇĀO - Campus "Luiz de Queiroz"/USP

Guidetti, Júlio Cesar Silva

Relaçōes econômicas entre custo e transação de um banco privado e crédito rural / Júlio Cesar Silva Guidetti. - - Piracicaba, 1998.

$85 \mathrm{p}$.

Dissertação (mestrado) - E Escola Superior de Agricultura Luiz de Queiroz, 1998. Bibliografia.

1. Banco privado 2. Crédito agricola 3. Custo operacional 4. Economia agrícola 5. Financiamento agricola 6 . Política agrícola I. Título 


\section{REIAÇÕES ECONÔMICAS ENTRE CUSTO DE TRANSAÇÃO DE UM BANCO PRIVADO E CRÉDITO RURAI}

JÚLIO CESAR SILVA GUIDETTI

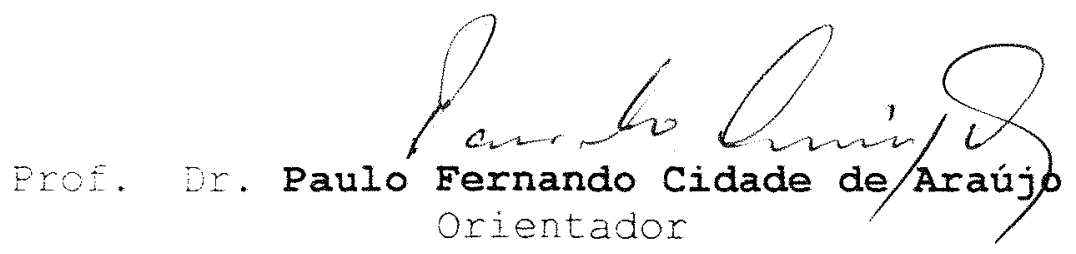


Dedico aos meus pais, Luiz e Ruth. 


\section{AGRADECIMENTOS}

Especiais agradecimentos ao Prof. Dr. Paulo

- Fernando Cidade de Araújo, pela orientação, paciência e amizade com a qual fui agraciado. Muito obrigado.

Aos Professores Ricardo Shirota e Mirian Rumenos Piedade Bacchi pelas sugestões e valiosas contribuições a realização deste trabalho.

Agradeço aos meus pais, Luiz e Ruth, pelo incentivo e compreensão durante o curso.

Aos Professores do Departamento de Economia e Sociologia Rural (DESR) da Escola Superior de Agricultura "Luiz de Queiroz" pela formação acadêmica.

Aos funcionários do DESR que se fizeram sempre presentes e dispostos a ajudar em todos os momentos.

Ao CNPq e à CAPES pelo apoio financeiro para o desenvolvimento da pesquisa. 


\section{S U M Á R I O}

Página

LISTA DE EIGURAS ...................... ii

IISTA $D E$ TABELAS $\ldots \ldots \ldots \ldots \ldots \ldots \ldots \ldots \ldots \ldots \ldots \ldots \ldots \ldots$

RESUMO $\ldots \ldots \ldots \ldots \ldots \ldots \ldots \ldots \ldots \ldots \ldots \ldots \ldots \ldots \ldots \ldots \ldots \ldots \ldots$

SUMMARY $\ldots \ldots \ldots \ldots \ldots \ldots \ldots \ldots \ldots \ldots \ldots \ldots \ldots \ldots \ldots$

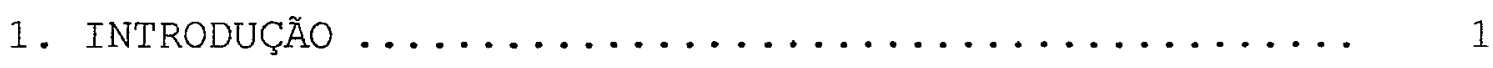

1.1. Definição do problema ................ 4

1.2. Objetivos ...................... 7

2. REVISÃO DE LITERATURA ..................... 9

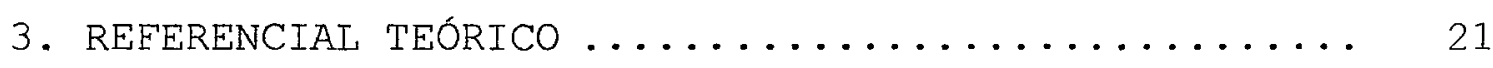

3.1. Custo bancário de transação ............. 21

3.2. Estimativas anteriores ............... 24

3.3. o modelo econômico ................. 27

3.4. o modelo estatístico ............... 30

3.5. Dados e definição das variáveis .......... 33

3.5.1. Procedimento metodológico ........ 33

3.5.2. Definição das variáveis ......... 33

4. BREVE CARACTERIZAÇÃO DA AGRICULTURA

NOS MUNICÍPIOS/REGIÕES EM ESTUDO ............. 
5. ANÁLISE DOS RESULTADOS .................. 44

5.1. Análise qualitativa ................. 44

5.2. Análise econométrica ................ 63

6. CONCLUSÕES $\ldots \ldots \ldots \ldots \ldots \ldots \ldots \ldots \ldots \ldots \ldots \ldots \ldots \ldots \ldots \ldots \ldots \ldots \ldots$

REEERÊNCIAS BIBLIOGRÁFICAS ............... 73

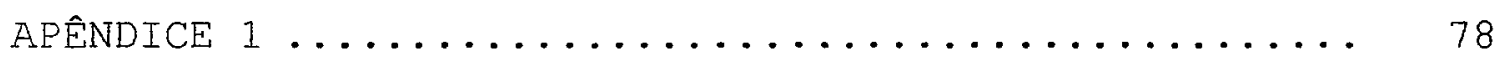

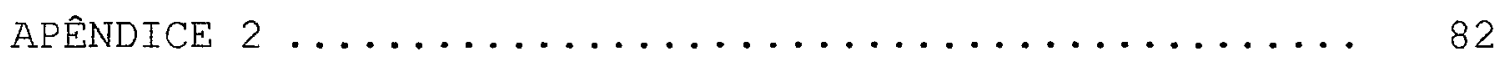




\section{IISTA DE FIGURAS}

Página

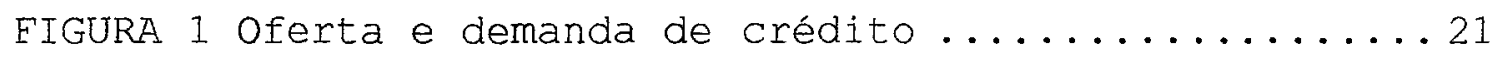
FIGURA 2 Composição da amostra completa ............ 44 FIGURA 3 Custo total de transação por unidade monetária de empréstimo ...........445 FIGURA 4 Faixas de custo total de transação .........449 FIGURA 5 Volume total aplicado em crédito rural .......52 FIGURA 6 Número de contratos em crédito rural ........54 FIGURA 7 Valor médio dos contratos de crédito rural ... 57 FIGURA 8 Aplicações em crédito rural/aplicações totais .. 59 EIGURA 9 Volume total aplicado em crédito não-agrícola .. 61 


\section{LISTA DE TABELAS}

Página

TABELA 1. Número de estabelecimentos por grupo de área total nos Municípios-sede das agências do banco, segundo as Regiões Geográficas ........ 36

TABELA 2. Estabelecimentos com informação de uso de assistência técnica, irrigação, adubos $e$ corretivos, controle de pragas e doenças, conservação do solo, energia elétrica nos Municípios-sede das agências do banco, segundo as Regiões Geográficas ... . . . . . . . 37

TABELA 3. Utilização das terras na amostra dos Municípios-sede das agências do banco, segundo as Regiões Geográficas ............. 38

TABELA 4. Pessoal ocupado na agricultura nos Municípios-sede das agências do banco, segundo as Regiões Geográficas .............. 39

TABELA 5. Valor da produção animal e vegetal nos estabelecimentos rurais dos Municípios-sede das agências do banco, segundo as Regiões Geográficas .......................41 
TABELA 6. Número de estabelecimentos rurais por agência bancária nos Municípios-sede das agências do banco, segundo as Regiões Geográficas ........................ 41

TABELA 7. Operações de crédito nos Muricípios-sede das agências bancárias, segundo as Regiões

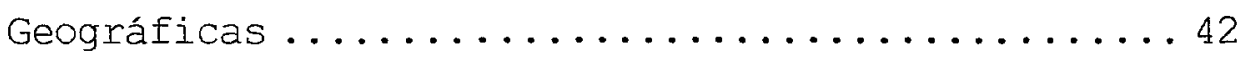

TABELA 8. Faixas de custo de transação por unidade monetária de empréstimo na amostra de agências do banco, segundo as Regiões Geográficas .... . . . . 44

TABELA 9. Valores mínimo, médio e máximo do custo de transação por unidade monetária de empréstimo na amostra das agências do banco, segundo as Regiões Geográficas ................... 45

TABELA 10. Faixas de custo total de transação na amostra de agências do banco, segundo as Regiões Geográficas, novembro/94 a julho/95 ....44

TABELA 11. Valores mínimo, médio e máximo de custo total de transação na amostra de agências do banco, segundo as Regiões Geográficas, novembro/94 a julho/95 ..............48

TABELA 12. Medidas de tamanho da carteira de crédito rural na amostra de agências do banco, segundo as Regiões Geográficas, novembro/94 a julho/95 .................50 
TABELA 13. Valores mínimo, médio e máximo do Volume Total Aplicado em Crédito Rural na amostra de agências do banco, segundo as Regiões Geográficas, novembro/94 a julho/95 ........ 53

TABELA 14. Medidas de tamanho da carteira de crédito rural na amostra de agências do banco, segundo as Regiões Geográficas, novembro/94 a julho/95 .............. 54

TABELA 15. Valores mínimo, médio e máximo do número de Contratos em Crédito Rural na amostra de agências do banco, segundo as Regiões Geográficas, novembro/94 a julho/95 ....... 55

TABELA 16. Eficácia no uso da tecnologia bancária no crédito rural na amostra de agências do banco, segundo as Regiões Geográficas, novembro/94 a julho/95 .............. 56

TABELA 17. Valores mínimo, médio e máximo de eficácia no uso da tecnologia bancária disponível na amostra de agências do banco, segundo as Regiões Geográficas, novembro/94 a julho/95 ..................... 58

TABELA 18. Relação entre aplicações em crédito rural e aplicações totais na amostra de agências do banco, segundo as Regiões Geográficas, novembro/94 a julho/95 ........ 59 
TFBELA 19. Valores mínimo, médio e máximo da relação entre aplicações em crédito rural e aplicações totais na amostra de agências do banco, segundo as Regiões Geográficas, novembro/94 a julho/95 ................60

TABELA 20. Faixas de Volume Total Aplicado em Crédito Não-agrícola na amostra de agências do banco, segundo as Regiões Geográficas, novembro/94 a julho/95 ........61

TABELA 21. Valores mínimo, médio e máximo do Volume Total Aplicado em Crédito Não-agrícola na amostra de agências do banco, segundo as Regiões Geográficas, novembro/94 a

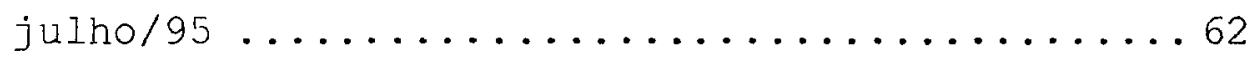

TABELA 22. Coeficientes de regressão e estatísticas do modelo I para estimar as relações entre custo total de transação do banco $\left(Y_{1}\right)$ e alguns fatores determinantes lem logarítmos) , 1994-1995 ................664

TABELA 23. Coeficientes de regressão e estatísticas do modelo II para estimar as relações entre custo de transação por unidade monetária de empréstimo do banco $\left(\mathrm{Y}_{2}\right)$ e alguns fatores determinantes (em logarítmos)，1994-1995 ..............67 


\title{
RETAÇÕES ECONÔMICAS ENTRE CUSTO DE TRANSAÇÃO \\ DE UM BANCO PRIVADO E CRÉDITO RURAI
}

\author{
Autor: JÚLIO CESAR SILVA GUIDETTI \\ Orientador: Prof. Dr. PAULO FERNANDO CIDADE DE ARAÚJO
}

\section{RESUMO}

O sistema financeiro desempenha papel fundamental na transferência de recursos dos agentes econômicos superavitários para agentes deficitários, proporcionando o aumento na taxa de investimento na economia.

Recentemente, O Plano Real gerou instabilidade em várias instituições do sistema financeiro do país. Com a estabilização da moeda, torna-se fundamental para os bancos a redução dos custos e a busca de maior eficiência na intermediação financeira.

Para tentar avaliar o estado em que se encontram os custos de transação nos bancos privados no Brasil, esta pesquisa analisa uma amostra de 205 agências de um banco comercial em três regiões geográficas, efetuando uma análise qualitativa e quantitativa das reláções econômicas entre custo operacional e alguns indicadores de desempenho da carteira de crédito rural e o volume total de aplicações. 
Os resultados demonstram que os custos médios de transação do banco são reduzidos. O tamanho da carteira de crédito e o grau de especialização da agência em operações de crédito rural são os fatores que mais fortemente influenciam os custos de transação do banco. Ou seja, aumentando-se o valor desses parâmetros é possível reduzir substancialmente os custos de transação por unidade monetária de empréstimos.

o valor médio dos contratos de crédito rural não se mostrou significativo, revelando pequena influência na redução dos custos de transação.

Finalmente, conclui-se que o banco em estudo deve buscar o conhecimento mais aprofundado da sua estrutura de custos. Esse conhecimento é também essencial aos formuladores de política agrícola, para que os mesmos possam ter uma visão mais realista das possibilidades de intervenção das autoridades monetárias no sistema financeiro. 


\title{
ECONOMIC RELATIONS BETWEEN TRANSACTION COSTS OF A PRIVATE BANK AND RURAL CREDIT
}

\author{
Author: JÚLIO CESAR SILVA GUIDETTI \\ Adviser: Prof. Dr. PAULO FERNANDO CIDADE DE ARAÚJO
}

\section{SUMMARY}

The financial system plays an essential role in the transference of financial surplus of economic agents to deficient agents, promoting an increase in the investiment rate.

The "Real Plan" has recently generated a strong instability in some of the Brazilian financial institutions. With the currency stabilization, it becomes essential to reduce costs and seek for an improvement in the financial intermediation.

In order to evaluate the state in which the costs of transaction of Brazilian private banks are, this research analyzes a sample of 205 commercial bank agencies located in three different geographical regions. Qualitative and quantitative analyses of economic relations between operational costs and some indicators of the rural credit loans performance and the total volume of loans were carried out. 
The results showed that the average cost of the bank is low. The size of the credit portfolio and the agency's specialization degree in rural credit operations are the factors that showed the strongest influence over the bank's transaction costs. In other words, it is substantially possible to reduce an agency's transaction costs by increasing the value of the these factors.

The average value of rural credit contracts was non-significant, revealing little influence over the reduction of transaction costs.

It was also concluded that the studied bank should seek a deeper knowledge of its cost structure. Such knowledge is also essential to enable those who take part in the formulation of the agricultural policy, to have a more realistic view of the possibilities of monetary authorities intervention in the financial system. 


\section{1 - INTRODUÇÃO}

Os sistemas financeiros oferecem serviços de pagamento, captam poupanças e concedem crédito; formam preços, negociam e diminuem os riscos resultantes dessas atividades. Esses serviços são prestados a familias, empresas e governo, através de instrumental próprio (moeda, cheques, cartões de crédito, títulos e ações) e instituições financeiras. A quantidade, qualidade e eficiência com que esses serviços são fornecidos determinam a parcela de contribuição que o sistema financeiro pode prestar à economia.

Os serviços financeiros visam baratear e assegurar o comércio de bens e serviços, a captação de depósitos/poupanças e a concessão e tomada de empréstimos. $\mathrm{Na}$ sua ausência, a economia se limitaria ao autofinanciamento e/ou escambo, impedindo a especialização da produção, da qual dependem as economias modernas. Os investimentos das unidades produtivas estariam reduzidos à capacidade de poupança do próprio produtor. As rendas seriam menores, impossibilitando a existência de complexas economias industriais e de serviços. 
As finanças são essenciais ao investimento e ao crescimento econômico. O fornecimento dos recursos poupados àqueles que podem usá-los de forma mais produtiva promoverá - aumento das rendas do poupador e do tomador do empréstimo. Porém, tais empréstimos poderão ser caros e arriscados, caso o sistema financeiro seja ineficiente. Essas dificuldades podem ser contornadas através do investimento autofinanciado (com recursos próprios), mas, geralmente, as empresas não possuem os recursos necessários quando surgem oportunidades de investimentos lucrativos. Para os investimentos públicos, há possibilidade de mobilização de poupanças adicionais através do sistema tributário, sistema financeiro (títulos do Tesouro) e empréstimos no exterior.

Em muitos paises, as finanças informais, como empréstimos entre parentes e amigos, e feitos por casas de penhor e agiotas, cumprem um importante papel. Porém, a expansão das economias exige serviços que só podem ser oferecidos por instituições formais - a exemplo dos bancos comerciais. Assim, as instituições formais tornam-se os principais intermediários entre os numerosos pequenos depositantes, os quais dão preferência a ativos líquidos, e os poucos grandes investidores que necessitam de empréstimos de prazos variados para financiar seus investimentos. Num sistema de mercado diversificado, o governo atua como regulador e usuário dos serviços financeiros. Embora sejam essenciais, os mercados financeiros apresentam forte instabilidade, vulnerabilidade e suscetibilidade a fraudes. 
A eficiência na utilização dos recursos financeiros é o que estabelece hoje a diferença entre países ricos e pobres (Banco Mundial, 1989). O sistema financeiro, atuando para aumentar sua eficiência, contribui para o crescimento econômico.

Os sistemas financeiros intermediam uma parte do investimento de um país; sendo uma outra parte do investimento das empresas e das familias financiada por poupanças próprias desses atores econômicos.

Por combinar poupança e investimento, o autofinanciamento possui a vantagem de englobar todos os custos referentes a informações, transações, monitoramento e execução. Em geral, são desnecessários contratos e cauções complexos ou outros mecanismos que aumentam o custo dos empréstimos. Contudo, o autofinanciamento possui uma grande desvantagem: as oportunidades de investimento podem não ser compatíveis com os recursos das pessoas físicas e jurídicas.

Direcionando parte dos recursos disponíveis para investimento, o sistema financeiro é fundamental na alocação da poupança nacional. Com a expansão do sistema financeiro, os bancos locais, instituições financeiras, mercados de títulos e bancos estrangeiros passam a atuar como fontes de recursos para os investidores. Com os sistemas financeiros funcionando adequadamente, o custo de transferência de recursos dos poupadores para os tomadores será reduzido, proporcionando elevação da taxa paga aos poupadores e redução do custo para os investidores.

No Brasil, durante o longo período de desequilíbrio macroeconômico pelo qual passamos, houve uma 
drástica redução no volume de recursos financeiros destinados ao crédito rural, penalizando fortemente o setor agrícola. A crise fiscal limitou a capacidade de poupança do governo, forçando a busca de novas fontes de financiamento junto ao setor privado nacional.

A poupança doméstica teve como função principal financiar o déficit público, prejudicando o financiamento de atividades produtivas, como a agricultura, a qual se caracteriza como atividade de risco e de ciclo produtivo mais ou menos longo.

Durante a década de 80 , os bancos obtiveram bons lucros com as altas taxas de inflação e financiamento da dívida pública.

Porém, segundo ARAÚJO \& ALMEIDA (1997), com a estabilização da moeda, abertura da economia e perspectiva de reformas constitucionais, é essencial que os bancos sejam mais eficientes na intermediação, através da redução de seus custos de transação, os quais, provavelmente sofrem forte influência da carteira de crédito rural.

\section{1. - Definição do problema}

Antes do Plano Real, segundo NAKANO (1992), o Brasil tinha um sistema financeiro atrofiado na sua função econômica básica de financiar a atividade produtiva e priorizou a função de financiar o déficit do setor público. os enormes lucros obtidos como agente de captação de recursos para o governo e apropriação de um fantástico 
volume de recursos, a título de imposto inflacionário sobre os depósitos à vista, permitiram que este setor crescesse na década de 80 a taxas pelo menos duas vezes maiores que a dos demais setores.

Em 1989, O setor financeiro nacional apropriou-se de cerca de 19\% do PIB, quase o dobro da contribuição relativa de todo o setor agropecuário. Portanto, o sistema financeiro é possivelmente um setor "inchado" que, com a estabilização da economia, deverá sofrer uma forte redução, adequando-se à nova realidade.

No sistema bancário brasileiro, em função dos elevados lucros obtidos e por ter sido um setor pouco competitivo, a disputa de mercado se fazia através de grandes investimentos em instalações suntuosas, sofisticações tecnológicas e diversificação de atividades, penalizando a eficiência operacional. O mesmo NAKANO (1992) sugere que os custos operacionais elevados dos bancos brasileiros e o seu poder de monopólio impunham spreads expressivos aos tomadores de empréstimos, quando considerados à luz de qualquer padrão internacional.

O Plano Real gerou uma forte instabilidade no sistema bancário. Isto se deve ao fato dos bancos terem obtido grandes lucros através do float ${ }^{1}$, quando havia altas taxas de inflação. O financiamento da dívida pública era uma operação lucrativa e sem riscos, pois o sistema de

1 Float - corresponde ao tempo decorrido entre a captação de determinados tipos de recursos pelos intermediários financeiros ltaxas, impostos, depósitos à vistal e o repasse desses recursos aos seus credores finais. Num ambiente de inflação elevada a aplicação desses recursos no over-night permitiu aos bancos lucros elevados. 
zeragem automática, junto à mesa do Banco Central, garantia os recursos necessários ao fechamento diário das contas bancárias (PESSÔA, 1996). Logo, a concessão de empréstimos e seus respectivos custos de transação não eram fatores preocupantes. Porém, com a estabilização da moeda, abertura da economia e necessidade de ampla reforma fiscal, é fundamental que os bancos revejam suas atividades sob o ângulo da eficiência, ou seja, reduzam seus custos de transação.

- custo de transação nas operações bancárias caracteriza-se como um bom indicativo da eficiência do agente financiador. O conhecimento detalhado das variáveis que compõem e influenciam este custo é fundamental à tomada de decisão dos intermediários financeiros com relação ao financiamento das atividades econômicas.

No Brasil, a pequena participação dos bancos privados no financiamento rural se justifica por dois fatores: nos últimos anos, ocorreu um racionamento nas instituições privadas de crédito, pois o financiamento da dívida pública era a alternativa de investimento mais atraente, rentável e segura. Além disso, a agricultura envolve riscos elevados, entre eles, o climático e o de renda.

Segundo PESSOAA (1996), nos bancos privados, a avaliação da rentabilidade da agência nãọ é feita por carteira especifica. Geralmente, ela é feita por agência, comparando-se a rentabilidade de todas as aplicações realizadas pela agência com seus custos totais de operação. Se uma agência for superavitária no conjunto de suas carteiras, ela continuará operando e somente se for 
continuamente deficitária será desativada.

De acordo com esse tipo de avaliação da
eficiência bancária, uma agência ineficiente no
financiamento agricola poderá manter sua carteira de
crédito rural operando, desde que no seu conjunto a agência
proporcione lucro ao banco. No entanto, uma agência
extremamente eficiente nas operaçóes de crédito rural
poderá ser fechada, desde que os demais serviços gerem
prejuízos maiores do que os lucros obtidos com o
financiamento rural.
Nesse quadro de referência, a estimação dá
influência do crédito rural sobre o custo total de
transação dos bancos, oficiais e privados, constitui
importante parâmetro de avaliação da eficiência na
intermediação financeira.

\section{2. - Objetivos}

Este trabalho tem por objetivo analisar qualitativa e quantitativamente a influência do crédito rural nos custos totais de transação de um banco privado. Tal esforço de pesquisa é válido, visto que o crédito rural é uma atividade excessivamente normatizada, envolvendo grande número de profissionais e uma tecnologia diferenciada que, provavelmente, exerce influência significativa sobre o custo total de transação.

Objetivamente, pretende-se efetuar uma análise das relações econômicas entre custo bancário de transação e alguns indicadores de desempenho da carteira de crédito 
rural e o volume total de aplicações do banco.

A análise qualitativa dará ênfase às estatisticas sobre número de contratos de crédito rural, valor médio dos contratos, proporção das aplicações em crédito rural, volume de aplicações em crédito rural por agência e volume de aplicações em crédito não-agrícola nas regiões centrooeste, Sudeste e Sul do país.

A análise quantitativa procurará estimar relações econométricas entre custo total de transação, algumas variáveis de desempenho da carteira de crédito rural e a escala de operações ativas de 205 agências do banco.

o banco privado em análise tem forte atuação nas principais regiões agrícolas do país. Além disso, a maioria das pesquisas disponíveis sobre custo bancário de transação focaliza principalmente bancos oficiais, sendo escassos e, até mesmo raros, trabalhos sobre bancos privados. 


\section{2 - REVISÃO DE IITERATURA}

Segundo ADAMS (1987a), o crédito agropecuário é uma das funções mais custosas desempenhadas pelos mercados financeiros formais, devido à dispersão geográfica, ao problema de garantia, ao pequeno tamanho dos empréstimos e aos riscos inerentes à agricultura.

ADAMS \& ROMERO (1987) destacam ainda outros problemas: os pequenos produtores rurais pedem empréstimos irregularmente e de pequenos valores, não têm antecedentes de crédito estabelecidos com os credores formais e geram rendas baixas e instáveis, tornando difícil a estimativa de sua capacidade de pagamento. Além disso, a política agrícola de muitos países obriga os credores a proporcionar uma assistência técnica custosa, na forma de crédito supervisionado/orientado e, ao mesmo tempo, impõe taxas de juros concessionárias. Logo, os intermediários devem cobrir os custos de preparar contratos que diminuam os riscos, os custos de monitoramento e acompanhamento dos contratos, além das perdas eventuais. A ampliação dos contratos financeiros rurais passa a depender então do quanto é possivel reduzir esses custos mediante dispositivos 
culturais, legais e institucionais.

os serviços oferecidos pelas instituições financeiras exigem a coleta e o processamento de um grande volume de informações. Além disso, as instituições precisam planejar, monitorar e fazer cumprir os contratos vigentes nas suas operações ativas e passivas. Assim, as instituições arcam com os custos administrativos (basicamente a folha de pagamento e o aluguel), impostos, custo do capital, cumprimento das normas e regulamentos estabelecidos pelas autoridades monetárias, e perdas por inadimplência. Tais encargos são denominados custos de transação. Para cobrir tais custos, as instituições cobram taxas por serviços específicos, além de juros sobre os empréstimos concedidos (GUIDETTI \& ARAÚJO, 1994a).

Para MEYER \& CUEVAS (1990), o custo bancário de trànsação corresponde à remuneração dos recursos humanos e materiais utilizados pelo banco nas operações de crédito, compreendendo desde a obtenção do dinheiro junto ao poupador, passando pela sua aplicação junto ao tomador, até a recuperação do dinheiro quando do vencimento do contrato. CUEVAS (1988) prega que os juros cobrados pelos bancos aos seus mutuários podem/devem incluir esse custo mais o custo dos riscos da operação, reservas para pagamentos duvidosos e lucro.

De acordo com ARAÚJO \& ALMEIDA (1997), os custos de transação podem ser separados em: custo de mobilização de depósitos e custo de concessão de créditos. O primeiro, corresponde aos recursos utilizados no manuseio de contas de depósitos, documentação, registros e publicação de balanços. o custo de concessão está associado ao 
processamento do empréstimo e gastos com monitoramento e recuperação do mesmo.

De acordo com ADAMS (1994), os custos de transação não são alocados em proporções fixas entre os tomadores de empréstimo. Clientes novos e não-preferenciais são submetidos a custos de transação maiores do que os praticados com clientes antigos e preferenciais. Isto ocorre devido a falta ou a imperfeição da informação obtida sobre os novos clientes e aos riscos de inadimplência.

Segundo ARAÚJO (1996), a assimetria de informação é um fator importante na análise da inadimplência no mercado de crédito. De acordo com esta abordagem, os fornecedores de crédito não têm o mesmo nível de informação sobre os tomadores e as possibilidades de sucesso dos empreendimentos financiados. Isto significa que embora o fornecedor saiba que os tomadores são diferenciados quanto à probabilidade de liquidação dos créditos contratados, é muito dificil avaliar e identificar tomadores que apresentem maior probabilidade de inadimplência.

É muito freqüente, a imposição governamental de taxas de juros máximas (abaixo das taxas comerciais e da inflação esperada) nos empréstimos rurais, o que gera um excesso de demanda, o qual é administrado pelos bancos com a adoção de medidas de racionamento. Isto, estabelece custos proibitivos aos pequenos produtores rurais na obtenção de crédito no mercado formal, restándo aos mesmos contrair empréstimos no mercado informal, submetendo-se então ao pagamento de taxas de juros maiores, porém, com menor custo de transação para o tomador (ADAMS, 1994). 
Atualmente, torna-se cada vez maior a necessidade das instituições financeiras identificarem sua estrutura de custos e promoverem inovações tecnológicas que diminuam o custo dos serviços de intermediação financeira. Os dirigentes de bancos devem acompanhar cuidadosamente a evolução dos indicadores de custo e avaliar a lucratividade dos vários serviços bancários. As decisôes gerenciais referentes à ampliação ou redução de determinadas atividades, implantação de novos serviços, devem ter como base o conhecimento de importantes aspectos tecnológicos, tais como economias de escala e de escopo e alocação dos recursos do banco entre funções alternativas ou complementares.

Ainda segundo ADAMS (1994), os custos de transação influem sobre os participantes do sistema financeiro de forma variável. Os custos de transação dos credores são fixos, independentemente do tamanho dos empréstimos concedidos. Dai os credores preferirem trabalhar com grandes empréstimos, que envolvem custos de transação pequenos em relação ao montante emprestado.

Já para tomadores e depositantes, os custos de transaçăo variam inversamente ao tamanho do empréstimo/depósito. Os tomadores e depositantes de pequenas quantias são muito sensíveis a mudanças nos custos de transação, enquanto os grandes tomadores e depositantes

$2^{2}$ e maneira simplificada, economia de escala consiste na redução do custo total médio quando se aumenta a escala de produção da firma. E economia de escopo consiste na redução do custo total médio quando se aumenta o número de produtos e/ou serviços produzidos pela firma. 
são mais influenciados pelas mudanças nas taxas de juros. os intermediários financeiros formais são criativos para minimizar impactos resultantes das restrições de política monetária. No entanto, a adoção dessas inovações pode acarretar aumento nos custos totais de intermediação. Por exemplo, os bancos passam a fazer vários empréstimos a uma mesma pessoa física ou jurídica, com valores abaixo do teto máximo por empréstimo estabelecido pela política creditícia vigente, acarretando aumento no custo de transação. ADAMS (1994) pondera que nos sistemas financeiros rigidamente controlados com grande quantidade de créditos direcionados (target credit), as atenções estão mais voltadas à elaboração de mecanismos para burlar leis e regulamentos do que à redução dos custos de transação.

Há autores que consideram as finanças informais a principal "incubadora" de tecnologias financeiras que visam reduzir o custo de transação, face à grande competição existente entre os agentes informais. O Grameen Bank de Bangladesh e a ACCION International na América Latina adotaram tecnologias (criação de grupos financeiros de auto-ajuda e de devoluções semanais dos empréstimos) que reduziram sensivelmente os custos da concessão de crédito a pequenos tomadores (GETUBIG et alii 1993, CHRISTEN, 1992). As finanças informais são mais ágeis do que as formais no desenvolvimento de técnicas ajustadas à mudanças na politica econômica. Na década de 80, na Bolívia hiperinflacionária, a maioria dos grupos informais de autoajuda converteu as obrigações contratuais, de pesos para dólares, protegendo-as da erosão do capital. Os bancos de 
desenvolvimento agrícola, ao contrário, persistiram em cobrar taxas negativas em seus empréstimos, resultando em perda do valor real dos fundos disponíveis.

Eacilidades de comunicação e transporte, sistemas judiçiais ativos e crescimento estável da economia são vitais para a redução dos custos de transação do sistema financtiro formal.

L. O uso excessivo de regulamentos e supervisão para forçar o sistema financeiro a realizar operações que fogem dos seus interessès pode aumentar o custo de transação. Cotas de empréstimos, restrições às taxas de juros e seguros de crédito são medidas que influem nos custos de transação e na distribuição dos empréstimos entre os participantes do sistema financeiro. A alteração do comportamento normal dos mercados financeiros, através de novos regulamentos, deve ser evitada, pois efeitos indesejáveis sobre os custos de transação poderão ocorrer.

Crédito direcionado e subsidios via taxas de juros tornam mais atrativa a intermediação financeira para os tomadores. Muitos deles podem decidir unilateralmente expandir o tamanho do subsídio recebido, mesmo sem a intenção de reembolsarem seus empréstimos. Por sua vez, os responsáveis pela concessão de empréstimos podem aceitar subornos para influir nas decisões. A fim de evitar tais distorções, as autoridades monetárias devem estimular inovações que reduzam os custos de transação para beneficiar tomadores e credores, criando um ambiente mais competitivo entre intermediários formais e informais.

MEYER \& CUEVAS (1990) citam vários fatores relevantes para explicar a magnitude dos custos de 
transação; entre eles: grau de desenvolvimento do sistema financeiro e nível de regulamentação do setor. Quanto mais amplo e sofisticado o sistema financeiro, maior será a disponibilidade de tecnologias de informática e de telecomunicações, logo, menor será o custo de transação. Quanto menor o grau de regulamentação do setor, envolvendo desde instrumentos de captação e aplicação, taxas e impostos, segmentação de mercado até o aparato legal, maior será a agilidade do sistema, proporcionando ganhos de produtividade e redução de custos. Por sua vez, a escala de operação e a diversidade de serviços oferecidos são também fatores fundamentais na determinação dos custos.

Nos países desenvolvidos, com um amplo e sofisticado sistema financeiro, a diferença entre o custo de captação dos recursos e a taxa de repasse ao tomador gira ao redor de $3 \%$ a $4 \%$, índice também praticado nos países em desenvolvimento com baixas taxas de inflação. Entretanto, nestes países, os custos de captação dos fundos são geralmente mais altos, assim como o custo do empréstimo para o tomador. Isto, porque, além da escassez relativa de capital, o sistema financeiro desses paises nem sempre possui o mesmo grau de sofisticação encontrado nos países de alta renda.

Nos países em desenvolvimento com altas taxas de inflação, esse spread é muito elevado, próximo ou até mesmo superior a 10\%. Tais paises apresentam um grande diferencial entre as taxas para credor e tomador, pois as dificuldades no levantamento de informações, a má utilização da tecnologia bancária e o uso ineficiente de recursos humanos e materiais contribuem para a elevação dos 
custos.

Outra questão estudada por vários autores é o papel dos custos de transação no racionamento do crédito. GONZÁIEZ VEGA (1987) defende a tese de que são elevados os custos de transação, tanto para tomadores quanto para credores, o que contribui para reduzir o tamanho dos mercados formais e restringir 0 acesso a empréstimos de muitos produtores rurais. ADAMS \& NEHMAN (1979) concluem que os custos de transação relativamente altos desincentivam os pequenos produtores rurais a obter crédito de fontes formais, com o que concordam ARAÚJO \& ALMEIDA (1992). Quando os recursos financeiros são emprestados a baixas taxas de juros, cria-se uma situação de excesso de demanda por crédito e o custo de transação pode ser utilizado pelas instituições financeiras formais como um desestímulo aos pequenos tomadores. Excessiva burocracia e rigidez do sistema financeiro atuam como dois pontos-chave nessa questão.

A administração ineficiente tem contribuído freqüentemente para o fracasso de algumas instituições especializadas de crédito. Por exemplo, GONZÁLEZ VEGA \& GARITA (1987), relatam que os custos de transação elevados implicam que a sociedade está gastando demasiados recursos na operação do sistema e, como resultado, o custo total dos fundos é elevado para os tomadores, o rendimento liquido para os depositantes é baixo e a rentabilidade dos intermediários financeiros termina sendo reduzida.

Para GRAHAM \& EIRESTINE (1987), os custos bancários diminuem quando são oferecidos incentivos especiais e tipos mais eficientes de empréstimo. Custos 
elevados de endividamento são muitas vezes resultantes do racionamento do crédito por parte dos bancos. A eliminação do crônico e generalizado excesso de demanda por crédito barato pode ser elemento essencial para induzir os credores a inovar e a reduzir alguns desses custos. Portanto, é necessário eliminar situações crônicas de excesso de demanda por crédito para que os bancos sejam estimulados a reduzir custos de transação.

Taxas reais de juros positivas obrigarão muitos tomadores a reduzir a demanda por empréstimos formais e farão com que os credores busquem novos clientes, incluindo pequenos e médios agricultores e empresas não-agrícolas localizadas no meio rural.

ADAMS (1987b) explica que os custos de transação são similares à fricção de um motor. Se reduzirmos a fricção, obteremos um funcionamento mais suave e prolongamos a vida útil do motor. Da mesma maneira, se os custos de transação (por unidade de dinheiro emprestado) diminuem, os mercados financeiros trabalham mais eficientemente e os intermediários financeiros "vivem" mais tempo. Por razões de eqüidade, é importante para os intermediários adotar inovações que reduzam custos, principalmente para os que procuram pequenos empréstimos e fazem pequenos depósitos.

Como destaca GONZÁLEZ VEGA (1987), taxas de juros baixas restringem $\circ$ acesso dos pobres a'os empréstimos formais. Os credores racionam os créditos para excluir os indivíduos mais custosos, de maior risco e menos influentes na sociedade. Os mecanismos usados pelos credores são os seguintes: redução no número de empréstimos a novos 
tomadores, preferência aos grandes tomadores que possuem mais garantias, concessão de créditos de curto prazo e com menores riscos de mercado. Esses procedimentos aumentam os custos de transação por unidade de crédito para muitos tomadores e reduzem a eficiência do processo de intermediação.

A demanda "repetitiva" (ao início de cada ano agrícola) por empréstimos pequenos, acompanhada do risco de crédito, eleva o custo de administrar empréstimos individuais. Os credores formais são sensíveis ao risco e ao custo. Assim sendo, necessitam de fortes incentivos para emprestar nas áreas rurais. Um incentivo poderá ser a elevação das taxas de juros dos empréstimos pelo menos para cobrir os custos de concessão de empréstimos (ADAMS, 1980 ). Porém, para oferecer uma alternativa real aos tomadores, os credores formais deveriam reduzir o processo burocrático. Um trâmite mais rápido das solicitações de empréstimo transformaria os credores formais em intermediários mais competitivos (BOUMAN, 1987).

Para BOURNE \& GRAHAM (1987), o aumento da taxa nominal de juros, justificado pelos objetivos de viabilidade institucional e pela necessidade de taxas de juros reais positivas, depende dos custos de transação e da inflação. Os custos de transação podem ser reduzidos através de reformas que estabeleçam maior responsabilidade para os funcionários das instituições de crédito. A disciplina de mercado imposta pelos depositantes poderia auxiliar a promover uma administração mais eficiente. Também é possível obter redução na morosidade e falta de pagamento mediante um sistema de informação mais ágil. Isto 
requer a reforma dos critérios de decisão, assim como a realização de estudos econométricos sobre os custos de emprestar, taxas de morosidade e movimentos nos preços dos insumos e produtos agrícolas.

A imposição de sanções contra os tomadores inadimplentes pode reduzir o custo dos empréstimos. Agências de crédito bem administradas que recuperam grande parte de seus empréstimos, costumam incorrer em custos entre 10 e $20 \%$ do valor dós empréstimos outorgados (DATEY, 1978).

CUEVAS \& GRAHAM (1987) destacam os contrastes na estrutura dos custos na organização geral de bancos públicos de desenvolvimento e de bancos privados que operam no setor agropecuário em países de baixa renda. O banco privado, que depende principalmente dos depósitos captados do público, é mais cauteloso e eficiente na avaliação de solicitações de empréstimo, em nível de agência. Em geral, delega grande parte das decisões às agências. o banco de desenvolvimento é centralizado e suporta uma pesada carga de custos administrativos derivada de condições e requisitos impostos por fontes externas de fundos.

Quando discutem as perspectivas do crédito rural no Brasil num cenário de estabilização econômica, BARRos \& ARAÚJO (1991a) recomendam como forma complementar de crédito rural, programas dirigidos aos pequenos produtores, financiados com recursos públicos orçamentários e do Tesouro Nacional, cedidos a taxas de juros preferenciais, tendo em vista as questões de pobreza rural e os desequilibrios regionais de renda. Isto porque o crescimento da participação do setor bancário privado na 
oferta de crédito rural ocorre preferencialmente em regiões que concentram produtores mais capitalizados e que operam em maior escala. 


\section{3 - REFERENCIAL TEÓRTCO}

\section{1. - Custo bancário de transação}

Os custos operacionais das instituições financeiras podem ser classificados em custos de captação de fundos e custos da atividade de emprestar, englobando o tempo e dinheiro gastos na análise das informações. Além dessas fontes, deverm ser considerados os custos decorrentes da inadimplência.

o impacto desses custos sobre a oferta e demanda de crédito pode ser demonstrado graficamente através da Figura 1.
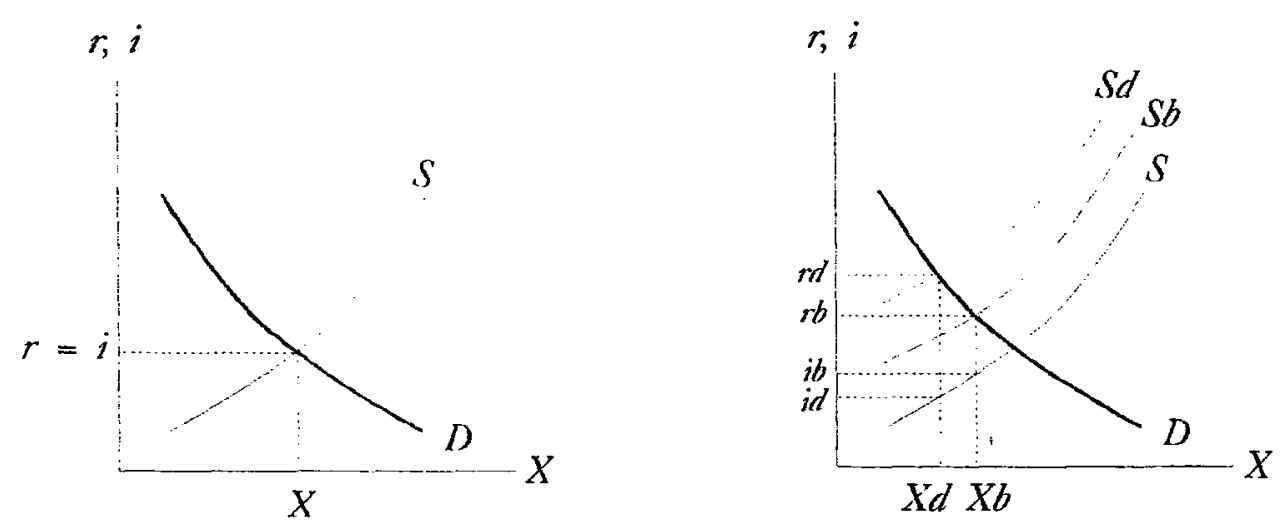

Fonte: BANCO MUNDIAL (1989)

Figura 1 - Oferta e demanda de crédito 
Nos diagramas da Eigura 1, o eixo horizontal mede a quantidade de empréstimos tomados ou concedidos por unidade de tempo $(X)$, enquanto o eixo vertical mede o custo de tomar emprestado $(r)$ e o retorno gerado pelos empréstimos (i). No primeiro diagrama, a procura de crédito na economia é representada pela curva descendente $D$. A inclinação negativa dessa curva reflete, a quantidade crescente (por unidade de tempo) de investimentos rentáveis à medida que diminui o custo dos empréstimos. A curva ascendente $S$ representa a oferta de crédito na economia, isto é, a quantidade de poupança oferecida a terceiros, seja diretamente ou através de intermediários, como bancos. Sua inclinação positiva se deve, em parte, ao aumento da poupança disponível para aquisição de ativos financeiros à medida que o retorno sobre tais ativos aumenta em relação ao retorno proporcionado por bens reais ou a investimentos fora do país. Se não existissem custos transacionais e regulamentação de juros, a taxa de juros determinada pelo mercado seria $r=i$ e a quantidade de crédito transacionada seria $X$.

Contudo, a tarefa de determinar a solvência dos mutuários custa dinheiro aos bancos/intermediários. No segundo diagrama, a quantia que os bancos cobram dos mutuários para o ressarcimento desse custo é representada pela curva $S d$. A distância vertical entre $S d$ e $S$ representa - valor desses custos transacionais, inclusive o custo de cobertura de inadimplências esperadas. Se os credores emprestassem diretamente aos mutuários, estariam dispostos a oferecer $X d$ na expectativa de ganhar $i d$, após deduzidos os custos esperados de transação. Os mutuários estariam 
pagando rd por esse volume de crédito $X d$. Logo, os custos de transação introduzem uma diferença entre os custos para - mutuário e o retorno do credor, reduzindo o volume de recursos emprestados.

Até certo ponto, a existência de bancos ou outros intermediários mais eficientes resulta do fato de os mesmos poderem reduzir os custos transacionais de emprestar e tomar emprestado. É o que demostra a curva Sb. A margem entre o custo para o mutuário e o retorno do credor é agora a sobretaxa cobrada pelo banco (spread). Supondo-se que o spread seja menor que o custo de emprestar diretamente, a quantia emprestada aumenta de $X d$ para $X b$; o retorno para os credores eleva-se de id para ib e o custo para os mutuários cai de rd para rb. Quanto mais os bancos forem capazes de reduzir os custos de transação, maiores serão esses efeitos (Banco Mundial, 1989). 


\section{2. - Estimativas anteriores}

MEYER \& CUEVAS (1990) relatam estimativas de custos bancários de transação de crédito rural por unidade monetária de empréstimo em diversos paises, quais sejam: Bangladesh, 0,9 a 2,9 \%; Filipinas, 1,6 a 5,4 \% Honduras, 3,4 a 10,0 \% República Dominicana, 8,8; Togo, 5,3\% e Nigéria, 9,5 ․ㅡ․

BARROS \& ARAÚJO (1991b) realizaram estudos sobre os custos de transação no crédito rural no Brasil, envolvendo agências bancárias (três bancos da região Nordeste, um da região Sudeste, um da região sull e duas cooperativas de crédito rural (uma na região sul e outra na região sudeste). A amostra em análise somou 25 observaçôes. Esses autores ajustaram um modelo de regressão múltipla para estimar as relações entre o custo bancário de transação no crédito rural e alguns fatores econômicos. o modelo utilizado foi:

$$
\begin{aligned}
& C T=f(v t, \text { vmc, pcr), onde: } \\
& C T=\text { custo de transação por agência bancária; } \\
& V t=\text { volume total de crédito rural concedido; } \\
& V m c=\text { valor médio do contrato; e, } \\
& p c r=\text { proporção de aplicações em crédito rural. }
\end{aligned}
$$

No processo de composição dos custos de transação (CT), esses autores subdividem as despesas das agências em dois tipos, ou seja: 
(a) despesas diretas, englobando $\left(a_{1}\right)$ despesas com pessoal; e, $\left(a_{2}\right)$ despesas específicas do crédito rural (como contratação de serviços de terceiros para avaliação, peritagem, fiscalização, assistência técnica, etc.l, diárias de funcionários, combustível, lubrificante, taxas e impostos;

(b) despesas indiretas, englobando $\left(b_{1}\right)$ despesas com pessoal envolvido com outras atividades; $\left(b_{2}\right)$ despesas fixas da agência (como aluguel, água e esgoto, luz, imposto predial, etc.); e, $\left(b_{3}\right)$ despesas variáveis da agência (como impressos, comunicações, publicidade, etc.).

o volume de recursos aplicados pela agência em crédito rural ( $v t$ ) indica as possibilidades de se explorar melhor o tamanho da carteira. o valor médio do contrato (vmc) indica a capacidade da agência em reduzir o uso de recursos materiais e humanos necessários para aplicar em crédito rural. A proporção das aplicações totais da agência correspondente ao crédito rural (pcr) indica a possibilidade da agência alocar melhor seus recursos entre crédito rural e os demais. A agência que possuir aplicações diversificadas poderia realocar recursos humanos e materiais entre crédito rural e outras atividades conforme a demanda por esses serviços. Como o crédito rural tem demanda estacional, é importante realocar recursos para outras atividades quando sua demanda for pequena e viceversa. Os resultados deste estudo sugerem que: a) um aumento de 10 \% no volume total emprestado sob a forma de crédito rural $(v t)$, coeteris paribus, tende a reduzir em cerca de 3,7 \% o custo da intermediação bancária (CT); b) um aumento de 10 응 nolor médio do contrato (vmc), 
apresenta tendência de reduzir em cerca de $3 \%$ custo bancário (CT); e, c) um aumento de $10 \%$ na proporção de aplicações da agência em crédito rural (pcr) influi na elevação do custo de transação (CT) em cerca de 1,5\%.

A conclusão a que chegam os autores é de que 0 sistema bancário, ao seguir as recomendações da eficiência econômica, deve atuar com grupo de produtores e/ou regiões que permitam ganhos de escala, com volume de crédito rural (vt) e valor médio dos contratos (vmc) elevados e onde possa haver uma diversificação de atividades de crédito ao longo do ano, diminuindo a proporção das aplicações em crédito rural $(p c r)$. Os pequenos produtores $e$ as regiões exclusivamente agrícolas seriam desfavorecidas nessa dinâmica.

GUIDETTI \& ARAÚJO (1994b) estimaram dois modelos econométricos para os custos bancários de transação nos empréstimos em crédito rural para 19 agências de um banco oficial na região sudeste. o primeiro modelo analisa o custo de transação por RS (real) emprestado em função do valor médio dos contratos (vmC), das aplicações totais em crédito rural ( $v t)$, da proporção das aplicações em crédito rural sobre as aplicações totais da agência (pcr) e do número de contratos $(n c)$. O segundo modelo relaciona o custo de transação por contrato com essas mesmas variáveis independentes. Nos dois modelos, a variável valor médio dos contratos (vmc) foi a de maior influência sobre os custos.

Em recente pesquisa, PESSÔA (1996) estimou dois modelos econométricos de custo bancário de transação dos empréstimos rurais em 62 agências de 4 bancos oficiais. 0 primeiro modelo relaciona o custo de transação por $\mathrm{R} S$ 
(real) emprestado com o valor médio dos contratos (vmc), as aplicações totais em crédito rural $(v t)$, a proporção do crédito rural em relação às aplicações totais da agência (pcr). O segundo modelo especifica o custo de transação por contrato èm função do valor médio dos contratos (vmc), da proporção do crédito rural em relação às aplicações totais da agência (pcr) e do número de contratos $(n c)$. Pôde-se constatar que o tamanho da carteira de crédito rural, medido através das variáveis vt e nc, e o valor médio dos contratos (vmc) são os fatores que mais fortemente influenciam os custos bancários de transação no crédito rural. O grau de especializaçâo da agência em crédito rural ( $p c r)$ também influencia os custos, porém, em menor intensidade.

\section{3. - Modelo econômico}

Neste estudo, o custo de transação de um banco é analisado segundo um modelo que estima as relações entre custo e alguns fatores econômicos importantes. 0 modelo assume que o custo total de transação das agências do banco é composto basicamente por despesas de pessoal e despesas administrativas. Em outras palavras, pressupõe-se que 0 custo operacional da agência é uma proxy do custo total de transação do banco.

Outra pressuposição do modelo é que o crédito rural exerce forte influência sobre o custo de transação, o que faz sentido face às características econômicas das 
regiões analisadas: Centro-oeste (Distrito Federal, Goiás, Mato Grosso e Mato Grosso do Sul); Sudeste (Espírito Santo, Minas Gerais, Rio de Janeiro e São Paulo); e, Sui (Paraná, Rio Grande do Sul e Santa Catarina).

Admite-se que o custo total de transação é influenciado pelos seguintes fatores: (i) eficácia no uso da tecnologia bancária utilizada no crédito rural, expressa pelo valor médio dos contratos; (ii) grau de especialização da agência em crédito rural, expresso pela relação entre aplicações em crédito rural e aplicações não-agrícolas da agência; e, (iii) tamanho da carteira de créditos da agência, expresso pela soma das aplicações em crédito rural e não-agrícola. Esta última variável procura captar o efeito-escala sobre o custo de transação.

Quanto maior a quantia emprestada por contrato de crédito rural, menores serão os custos de transação. Espera-se, portanto, uma relação inversa entre este fator e - custo de transação do banco.

A proporção das aplicações em crédito rural é outro fator relevante para explicar a magnitude dos custos. o efeito deste fator sobre os custos pode ser positivo ou negativo. Desde que a maioria das atividades da agência esteja centralizada na agricultura, quanto maior a proporção das aplicações em crédito rural, maior será o custo de transação, pois aumentarão os gastos com recursos humanos e materiais nesta modalidade de empréstimo. Por outro lado, agências que apresentam diversificação maior em suas aplicações, poderão reduzir o seu custo total de transação, pois somente intensificarão seus empréstimos ao setor rural quando a demanda por este tipo de empréstimo 
assim o exigir.

o volume total de aplicações da agência, é outro fator que influencia os custos bancários de transação. É de se esperar que as agências de maior escala tenham menor custo médio de transação. Embora o custo total de transação aumente quando aumentam as operações ativas do banco, o custo total por unidade monetária de empréstimos deverá diminuir. Ou seja, esperam-se retornos crescentes à escala. Uma possiviel restrição do modelo econômico proposto é que, devido à falta de dados, a taxa de inadimplência não pode ser devidamente especificada. No Brasil, há evidências empiricas sugerindo que na medida em que aumenta o tamanho do tomador aumenta também a inadimplência, reduzindo, assim, as possíveis vantagens que outros fatores econômicos poderiam exercer sobre a redução dos custos de transação (ARAúJo, 1996).

As relações econômicas entre custo total de transação e os fatores explicitados no modelo podern ser expressas por:

$$
\begin{aligned}
& C T=f(V M C, E A, T C N A) \text {, onde: } \\
& C T=\text { custo total de transação por agência; } \\
& V M C=\text { valor médio dos contratos de crédito rural } \\
& \quad \text { por agência; } \\
& E A=\text { grau de especialização da agência è crédito rural; } \\
& E O A=\text { escala de operações da agência. }
\end{aligned}
$$


Para identificar o efeito-escala, uma versão alternativa do modelo será testada, estabelecendo relações entre o custo total de transação por unidade monetária de empréstimos (CTMe) e os mesmos fatores explicativos da equação 2 .

Especificadas as relações esperadas entre o custo total de transação e os fatores econômicos ligados ao crédito rural e crédito total, define-se, a seguir, o modelo estatístico a ser utilizado na estimação e teste das relações e hipóteses sugeridas pelo modelo econômico.

\title{
3.4. - Modelos estatísticos
}

\begin{abstract}
Para estimar as relações econométricas entre os custos de transação do banco (CT e CTMe) e fatores econômicos associados às carteiras de crédito rural e à escala de operações (VMC, EA e EOA) são ajustados dois modelos de regressão múltipla, linear nos logarítmos.
\end{abstract}

Os modelos contemplam uma amostra de 205 agências do banco; sendo também analisadas sub-amostras das regiões Centro-oeste, Sudeste e Sul.

As formas gerais dos modelos são: 
Modelo I

$$
\begin{aligned}
& Y_{1}=f\left(X_{1}, X_{2}, X_{3}\right), \text { ou seja, } \\
& \log Y_{1}=a+b_{1} \cdot \log X_{1}+b_{2} \cdot \log X_{2}+b_{3} \cdot \log X_{3}+e
\end{aligned}
$$

onde:

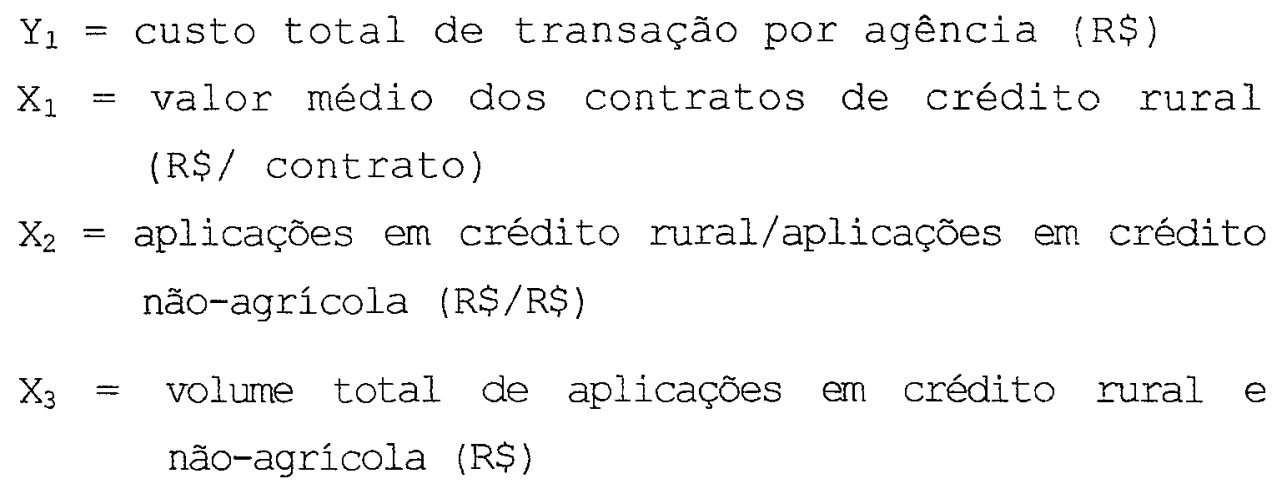

\section{Modelo II}

$$
\begin{aligned}
& Y_{2}=f\left(X_{1}, X_{2}, X_{3}\right), \text { ou seja, } \\
& \log Y_{2}=a+b_{1} \cdot \log X_{1}+b_{2} \cdot \log X_{2}+b_{3} \cdot \log X_{3}+e
\end{aligned}
$$

onde:

$Y_{2}=$ custo total de transação por unidade de valor emprestado (R\$/RS)

$\mathrm{X}_{1}=$ valor médio dos contratos de crédito rural (RS/ contrato)

$\mathrm{X}_{2}=$ aplicações em crédito rural/aplicações em crédito rão-agrícola (RS/RȘ)

$\mathrm{x}_{3}=$ volume total de aplicações em crédito rural e nãoagrícola (RS) 
A partir dessas formas gerais, serão estimados e interpretados os coeficientes da regressão $\left(b_{i}\right)$, os desvios-padrão dos coeficientes da regressão, o coeficiente de determinação $\left(R^{2}\right)$ e os respectivos erros(e).

o teste $t$ determina a significância estatistica dos coeficientes da regressão. O teste $F$ testa a significância do coeficiente de correlação múltipla dado pelo grau de correlação entre a variável dependente e o conjunto de variáveis independentes. A hipótese nula a ser testada é que os coeficientes da regressão não são significativamente diferentes de zero.

No Modelo I, é esperado sinal negativo para o coeficiente da variável valor médio dos contratos de crédito rural $\left(\mathrm{X}_{1}\right)$; para o coeficiente da variável escala de operações da agência $\left(X_{3}\right)$, espera-se sinal positivo.

No caso particular da variável aplicações em crédito rural sobre aplicações não-agrícolas $\left(X_{2}\right)$, o sinal poderá ser positivo ou negativo em razão das considerações feitas anteriormente (em 3.3).

No Modelo II, é esperado que o sinal do coeficiente de regressão da variável escala de operações da agência $\left(X_{3}\right)$ seja negativo. 


\section{5. - Dados e deśinição das yariáveis}

\subsection{1. - Procedimento metodológico}

Os dados para esta pesquisa foram fornecidos por um banco comercial que possui uma rede integrada de 614 agëncias em todas as regiões do Brasil. Os dados são mensais e referem-se ao período novembro/94 - julho/95. Para estimar custo total de transação do banco, volume de aplicações em crédito rural, volume total de aplicações em crédito (escala) e valor médio dos contratos de crédito rural serão utilizados os dados referentes à posição de cada mês do período em análise, ou seja, dados de fluxo. Todos os valores monetários foram corrigidos pelo IGP/DI para o mês julho de 1995.

\subsection{2. - Definição das variáveis}

A variável dependente $Y_{1}$ é $O$ custo total de transação por agência, expresso em R\$. É a soma das despesas de pessoal (inclusive encargos sociais) e despesas administrativas (aluguel, água e esgoto, luz, imposto predial, impressos, comunicações, diárias, etc.) no período de nove meses.

A variável dependente $\mathrm{Y}_{2}$ - custo total de transação por unidade de valor emprestado - é expressa em RS/RS. É a soma das despesas de pessoal e das despesas 
administrativas sobre o valor total das aplicaçoes feitas no período.

A variável independente $x_{i}$ é o valor médio dos contratos de crédito rural, em RS/contrato. É mediảa pela divisão do volume total de aplicaçõcs om crédito rural pelo número de contratos.

A variável independente $x_{2}$ é a relação entre aplicações em crédito rural e aplicações não-agrícolas da agência, em RȘ/RȘ.

A variável $\mathrm{X}_{3}$ é o volume de aplicações em crédito total (escala de operações) em R\$ e obtida pela soma das estatisticas oficiais do banco. 


\section{4 - BREVE CARACTERIZAÇÃO DA AGRICULTURA NOS MUNICÍPIOS/REGIÕES EM ESTUDO}

Dentre as 614 agências que compõem a rede de atendimento do banco privado em estudo, foram selecionadas 205 agências, que correspondem a cerca de 33,39\% do total do banco. As agências bancárias selecionadas nesta pesquisa constam do Apêndice 1 .

Neste capítulo, a maior parte das análises é fundamentada em dados do Censo Agropecuário 1995-1996, exceção feita à distribuição regional das agências bancárias e às operações de crédito, cujos dados são do Banco Central do Brasil, de maio de 1998.

A Tabela 1, a seguir, mostra o número de estabelecimentos por grupo de área total nos municípios onde se localizam as agências da amostra em análise, segundo as Regiões Geográficas. 
Tabela 1 - Número de estabelecimentos por grupo de área total nos Municípios-sede das agências do banco, segundo as Regiōes Geográficas.

\begin{tabular}{|c|c|c|c|c|c|c|c|}
\hline \multirow[b]{2}{*}{ Amostra } & \multicolumn{7}{|c|}{$\begin{array}{c}\text { Estabelecimentos segundo os grupos de área total } \\
\text { (ha), em } 31 / 12 / 1995\end{array}$} \\
\hline & $\begin{array}{l}\text { Menos } \\
\text { de } 10\end{array}$ & $\begin{array}{c}10 \text { a } \\
\text { menos } \\
\text { de } 100\end{array}$ & $\begin{array}{l}100 \text { a } \\
\text { menos } \\
\text { de } 200\end{array}$ & $\begin{array}{l}200 \text { a } \\
\text { menos } \\
\text { de } 500\end{array}$ & $\begin{array}{l}500 \text { a } \\
\text { menos } \\
\text { de } 2000\end{array}$ & $\begin{array}{l}2000 \\
\text { mais }\end{array}$ & $\begin{array}{l}\text { Sem } \\
\text { relato }\end{array}$ \\
\hline Total & 63.581 & 98.863 & 14.033 & 12.989 & 8.873 & 2.141 & 213 \\
\hline Centro-oeste ${ }^{a}$ & 5.239 & 12.531 & 4.087 & 5.329 & 5.192 & 1.696 & 45 \\
\hline Sudeste & 16.236 & 24.151 & 4.300 & 3.248 & 1.318 & 157 & 57 \\
\hline $\mathrm{Sul}{ }^{\mathrm{b}}$ & 42.106 & 62.181 & 5.646 & 4.412 & 2.363 & 288 & 111 \\
\hline
\end{tabular}

Fonte: Censo Agropecuạirio 13351936.

a Não há informação disponível sobre o DF.

b Não há informação disponivel sobre o Estado de SC.

É possível constatar que $80 \%$ dos estabelecimentos rurais dos municípios/regiões em estudo são de pequeno (menos de 10 ha) e médio porte (10 a menos de 100 ha), exceção feita aos municípios da região centro-oeste, onde é também expressiva a proporção de estabelecimentos de grande porte $(48$ 응)

Da análise da Tabela 2, constata-se que os estabelecimentos rurais da região sul foram os que apresentaram os maiores índices de tecnologia moderna. Provavelmente, devido ao fácil acesso à informação e nível de escolaridade dos proprietários rurais. O Centro-oeste apresentou bons índices de adoção de tecnologia, 
sobrepujando até mesmo a região sudeste em quatro dos aspectos analisados (assistência técnica, controle de pragas e doenças, conservação do solo e energia elétrica).

Tabela 2 - Estabelecimentos coll informação de uso de assistência técnica, irrigação, adubos e corretivos, controle de pragas e doenças, conservação do solo, energia elétrica nos Municipios-sede das agências do banco, segundo as Regiões Geográficas.

\begin{tabular}{|c|c|c|c|c|c|c|}
\hline \multirow[b]{2}{*}{ Amostra } & \multicolumn{6}{|c|}{ Porcentagem de estabelecimentos com declaração de uso de } \\
\hline & $\begin{array}{l}\text { Assistência } \\
\text { técnica }\end{array}$ & $\begin{array}{l}\text { Adubos e } \\
\text { corretivos }\end{array}$ & $\begin{array}{l}\text { Controle } \\
\text { de pragas } \\
\text { e doencas }\end{array}$ & $\begin{array}{l}\text { Conservação } \\
\text { do solo }\end{array}$ & Irrigação & $\begin{array}{l}\text { Energia } \\
\text { elétrica }\end{array}$ \\
\hline Total & $38,41 \%$ & $58,02 \frac{\circ}{\circ}$ & $76,07 \%$ & $39,74 \%$ & $7,78 \%$ & $59,23 \%$ \\
\hline $\begin{array}{l}\text { Centro- } \\
\text { oeste }^{a}\end{array}$ & $38,32 \%$ & $36,31 \%$ & $68,70 \div$ & $29,62 \%$ & $3,02 \%$ & $48,28 \%$ \\
\hline Sudeste $^{b}$ & $17,26 \%$ & $36,83 \%$ & $44,00 \%$ & $17,73 \frac{\circ}{\circ}$ & $13,82 \%$ & $35,43 \%$ \\
\hline $\mathrm{Sul}{ }^{\mathrm{C}}$ & $47,37 \%$ & $73,29 \%$ & $91,76 \%$ & $51,98 \%$ & $6,62 \%$ & $72,47 \%$ \\
\hline
\end{tabular}

Fonte: Censo Agropecuário 1995-1996.

a Não há informação disponível sobre o DF.

b Não há informação disponível sobre o Estado de SP.

C Não há informação disponível sobre o Estado de SC.

A Tabela 3 demonstra a utilização das terras pelos estabelecimentos rurais na amostra dos municípiossede das 205 agências do banco, segundo as Regiões Geográficas do país. 


\begin{abstract}
Tabela 3 - Utilização das terras na amostra dos Municipiossede das agências do banco, segundo as Regiões Geográficas.
\end{abstract}

\begin{tabular}{|c|c|c|c|c|c|}
\hline \multirow[b]{2}{*}{ Amostra } & \multirow[b]{2}{*}{$\begin{array}{c}\text { Área } \\
\text { total } \\
\text { (mil ha) }\end{array}$} & \multicolumn{4}{|c|}{ Utilização das terras em 31/12/1995 } \\
\hline & & $\begin{array}{c}\text { Lavouras } \\
\text { permanentes } \\
\text { e } \\
\text { temporárias }\end{array}$ & $\begin{array}{c}\text { Pastagens } \\
\text { naturais e } \\
\text { artificiais }\end{array}$ & $\begin{array}{c}\text { Matas } \\
\text { naturais e } \\
\text { plantadas }\end{array}$ & $\begin{array}{c}\text { Lavouras } \\
\text { em repouso } \\
\text { e } \\
\text { produtivas } \\
\text { não usadas }\end{array}$ \\
\hline Total & $24.360,2$ & $4.848,4$ & 13.359 .4 & $4.394,2$ & 756,1 \\
\hline $\begin{array}{l}\text { Centro- } \\
\text { oeste }^{a}\end{array}$ & $12.705,3$ & $1.157,3$ & $7.703,9$ & $3.006,2$ & 376,6 \\
\hline Sudeste & $4.347,5$ & $1.231,9$ & $2.330,7$ & 473,2 & 129,8 \\
\hline $\mathrm{sul}^{\mathrm{b}}$ & $7.307,4$ & $2.459,2$ & $3.324,9$ & 914,8 & 249,7 \\
\hline
\end{tabular}

Fonte: Censo Agropecuário 1995-1996.

a Não há informação disponível sobre o DF.

b Não há informação disponivel sobre o Estado de SC.

Verifica-se que a área dos estabelecimentos da amostra total corresponde, praticamente, à área total do Estado de São Paulo (24,88 milhões de ha). Parte expressiva das terras é destinada às pastagens naturais e artificiais, predominando inclusive sobre o total de terras utilizadas pela produção agrícola, ou seja, o somatório das áreas ocupadas com lavouras permanentes e temporárias e áreas produtivas em descanso. 
Tabela 4 - Pessoal ocupado na agricultura nos Municípiossede das agências do banco, segundo as Regiões Geográficas.

\begin{tabular}{lccccc}
\hline & \multicolumn{5}{c}{ Pessoal ocupado em 31/12/1995 } \\
\cline { 2 - 6 } Amostra & Total & $\begin{array}{c}\text { Total de } \\
\text { homens }\end{array}$ & $\begin{array}{c}\text { Homens } \\
\text { menores de } \\
14 \text { anos }\end{array}$ & $\begin{array}{c}\text { Total de } \\
\text { mulheres }\end{array}$ & $\begin{array}{c}\text { Mulheres } \\
\text { mores de } \\
\end{array}$ \\
\cline { 2 - 6 } & & & 36.209 & 209.878 & 28.624 \\
\hline Total & 744.062 & 534.184 & 8.571 & 28.622 & 7.170 \\
Centro-oeste a & 106.799 & 78.177 & 7.819 & 53.824 & 6.000 \\
Sudeste & 226.046 & 172.222 & 19.819 & 127.432 & 15.454 \\
\hline
\end{tabular}

Fonte: Censo Agropecuário 1995-1996.

a Não há informação disponível sobre o DF.

b Não há informação disponivel sobre o Estado de SC.

Segundo os dados da Tabela 4, predomina o emprego de mão-de-obra masculina. A região sudeste apresenta a maior discrepância quanto à taxa de composição da mão-deobra ocupada pelos estabelecimentos rurais, alcançando índices superiores a 75\% em favor da mão-de-obra masculina. Nas demais regiões, assim como na amostra total, o índice de ocupação de mão-de-obra masculina situase ao redor de $71 \%$. Menores de 14 anos trabalhando em atividades agropecuárias chegam a representar 8,71 음 da força de trabalho nos estabelecimentos rurais dos municipios-sede das agências do banco; sendo $6,78 \%$ no caso do sexo masculino e 13,64\% no feminino. A região sudeste apresenta a menor taxa de utilização de mão-de-obra infantil, 6,11\%, assim distribuida: 4,54\% para meninos e 
11,15 para meninas. Esses resultados parciais do último Censo Agropecuário evidenciam, mais uma vez, o longo caminho a percorrer em termos de educação e qualidade dos recursos humanos no meio rural.

As estatisticas da Tabela 5 mostram a importância econômica dos municípios-sede das agências bancárias. Elas responderam por cerca de 5,7 bilhões de reais em valor de produção vegetal e animal em 1995. O valor da produção vegetal é maior do que o da produção animal, principalmente nos municípios do Sudeste e Sul; os do Centro-oeste apresentam maior valor na produção animal. 
Tabela 5 - Valor da produção animal e vegetal nos estabelecimentos rurais dos Municípios-sede das agencias do banco, segundo as Regiōes Geográficas ${ }^{a}$.

\begin{tabular}{|c|c|c|c|c|c|}
\hline \multirow{3}{*}{ Amostra } & \multicolumn{5}{|c|}{ Valor da produção (mil reais) } \\
\hline & \multirow[t]{2}{*}{ TotaI } & \multicolumn{2}{|c|}{ Vegetal } & \multicolumn{2}{|c|}{ Animal } \\
\hline & & Total & Lavouras & Total & $\begin{array}{c}\text { De grande } \\
\text { porte }\end{array}$ \\
\hline Total & 5.701 .951 & $\begin{array}{c}3.676 .915 \\
(64,49)\end{array}$ & 3.491 .367 & $\begin{array}{c}2.025 .036 \\
(35,51)\end{array}$ & 1.296 .815 \\
\hline Centro-oeste ${ }^{b}$ & 1.235 .919 & $\begin{array}{l}573.748 \\
(46,42)\end{array}$ & 566.476 & $\begin{array}{l}662.171 \\
(53,58)\end{array}$ & 613.818 \\
\hline Sudeste ${ }^{c}$ & 1.901 .936 & $\begin{array}{c}1.331 .029 \\
(69,98)\end{array}$ & 1.248 .619 & $\begin{array}{l}570.907 \\
(30,02)\end{array}$ & 319.781 \\
\hline $\operatorname{SuI}^{d}$ & 2.564 .096 & $\begin{array}{c}1.772 .138 \\
(69,11)\end{array}$ & 1.676 .272 & $\begin{array}{c}791.958 \\
(30,89)\end{array}$ & 363.216 \\
\hline
\end{tabular}

Fonte: Censo Agropecuário 1995-1996.

a os números entre parênteses expressam valores porcentuais.

b Não há informação disponivel sobre o Estado de MT e DF.

C Não há informação disponível sobre o Estado de RJ.

d Não há informação disponível sobre o Estado de SC.

A Tabela 6 expõe a relação número de estabelecimentos rurais por agência bancária nos municípios-sede, segundo as Regiões Geográficas. Trata-se de indicador importante para definir a estratégia de atuação do banco nos mercados financeiros rurais. 
Tabela 6 - Número de estabelecimentos rurais por agência bancária nos Municípios-sede das agências do banco, segundo as Regiões Geográficas ${ }^{a}$.

\begin{tabular}{|c|c|c|c|}
\hline Amostra & $\mathrm{N}^{\circ} \mathrm{e}$ & Lecimentos & rurais/agência \\
\hline & Mínimo & Médio & Máximo \\
\hline Total & 9 & 139 & 1965 \\
\hline Centro-oeste & 76 & 222 & 982 \\
\hline Sudeste & 9 & 70 & 1965 \\
\hline Sul & 28 & 200 & 1650 \\
\hline
\end{tabular}

Fonte: Censo Agropecuário 1995-1996. BANCO CENTRAL DO BRASIL (1998a).

a Excluidas as agências e propriedades localizadas em capitais de Estados e no Distrito Federal, bem como municipios com pouca representatividade na produção agrícola. Incluem-se neste último caso: Foz do Iguaçu (PR), Novo Hamburgo (RS), Ribeirão Preto (SP), Serrana (SP), Tramandai (RS) e Vila Velha (ES).

$\mathrm{Na}$ análise desses dados, encontram-se relações incomuns entre as máximas obtidas em alguns municipios, onde uma agência teria que responder pelo atendimento de cerca de 1500 estabelecimentos rurais, o que torna muito difícil a oferta de bons serviços bancários. Por sua vez, alguns valores mínimos obtidos em municípios do sudeste (Jundiaí) e Sul (Maringá), são atípicos, atingindo relações muito abaixo do esperado, o que à primeira vista poderia inviabilizar, em termos financeiros, a manutenção de carteiras agrícolas em algumas agências.

A Tabela 7 mostra as operações de crédito na amostra dos municípios-sede das agências bancárias existentes, segundo as Regiões Geográficas. 
Tabela 7 - Operações de crédito nos Municípios-sede das agências bancárias, segundo as Regiões Geográficas.

\begin{tabular}{lccccc}
\hline & \multicolumn{5}{c}{ Operações de crédito (mil reais) } \\
\cline { 2 - 6 } Amostra & $\begin{array}{c}\text { Financ. } \\
\text { Rurais }\end{array}$ & & Outros & $\%$ & Total \\
\hline Total & 6.978 .512 & 5,33 & 124.053 .526 & 94,67 & 131.033 .534 \\
Centro-oeste & 1.492 .789 & 8,17 & 16.777 .085 & 91,83 & 18.270 .158 \\
Sudeste & 3.446 .313 & 3,81 & 86.929 .108 & 96,19 & 90.376 .062 \\
Sul & 2.039 .410 & 9,11 & 20.347 .333 & 90,89 & 22.387 .314 \\
\hline
\end{tabular}

Fonte: BANCO CENTRAL DO BRASIL (1998b).

Pode-se afirmar que uma parcela pouco significativa (menos de 10\%) do total de recursos oferecidos pelor setor bancário teve por objetivo o financiamento rural. Isto ratifica a tendência de crescente escassez de recursos financeiros fornecidos pelo SNCR aos agricultores. 


\section{5 - ANÁLISE DOS RESULTADOS}

\section{1. - Análise qualitativa}

A amostra de 205 agências bancárias apresenta a seguinte composição por região geográfia(Figura 2):

Figura 2 - Composição da Amostra Completa (205 agências)

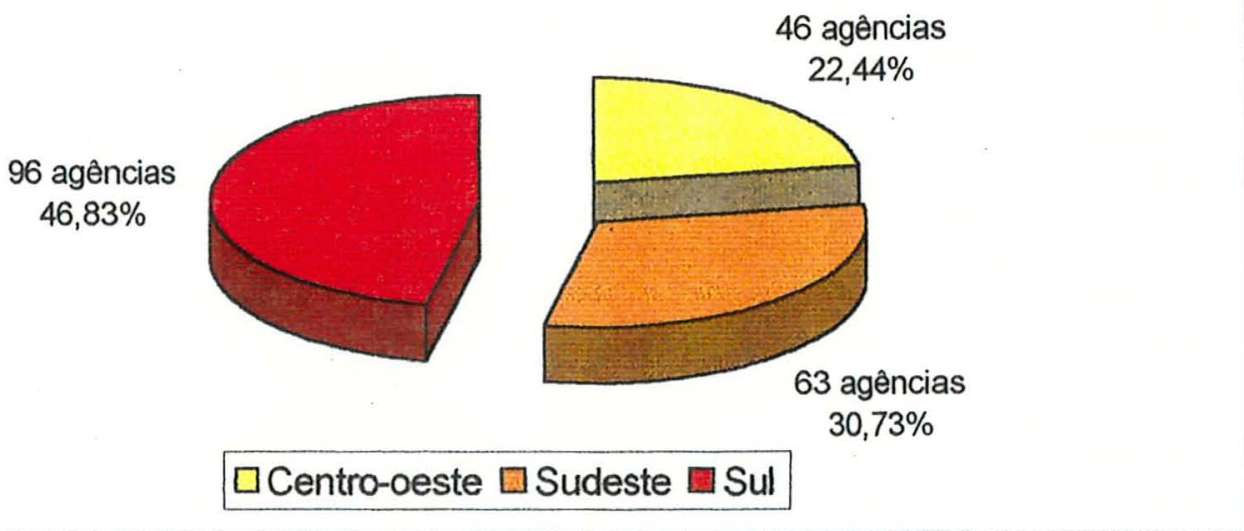

Fonte: Dados da Pesquisa.

$\mathrm{Na}$ abordagem qualitativa dos dados referentes aos custos de transação e à tecnologia bancária do banco, são analisados fatores gerais da estrutura bancária, tais como: custo de transação por unidade de valor emprestado e o custo total de transação por agência. São também 
considerados os seguintes fatores inerentes a carteira de crédito rural: tamanho da carteira, eficácia no uso da tecnologia bancária disponível e grau de especialização da agência.

Quanto ao custo de transação por unidade monetária de empréstimo, medido pela relação $\mathrm{R} \$$ gastos por R\$ emprestado, as agências foram classificadas em quatro faixas de custo (ver Tabela 8 e Figura 3).

Tabela 8 - Faixas de custo de transação por unidade monetária de empréstimo na amostra de agências do banco, segundo as Regiões Geográficas.

\begin{tabular}{lcccc}
\hline & \multicolumn{4}{c}{ Número de Agências } \\
\cline { 2 - 5 } Faixas de Custo & Total & Centro-oeste & Sudeste & Sul \\
\hline (1) $0 \%$ a $2,50 \%$ & 142 & 38 & 39 & 65 \\
(2) $2,51 \%$ a $4,99 \%$ & 49 & 7 & 16 & 26 \\
(3) $5,00 \%$ a $7,50 \%$ & 11 & 1 & 5 & 5 \\
(4) 7,51\% a $10 \%$ & 3 & 0 & 3 & 0 \\
\hline
\end{tabular}

Fonte: Dados da Pesquisa.

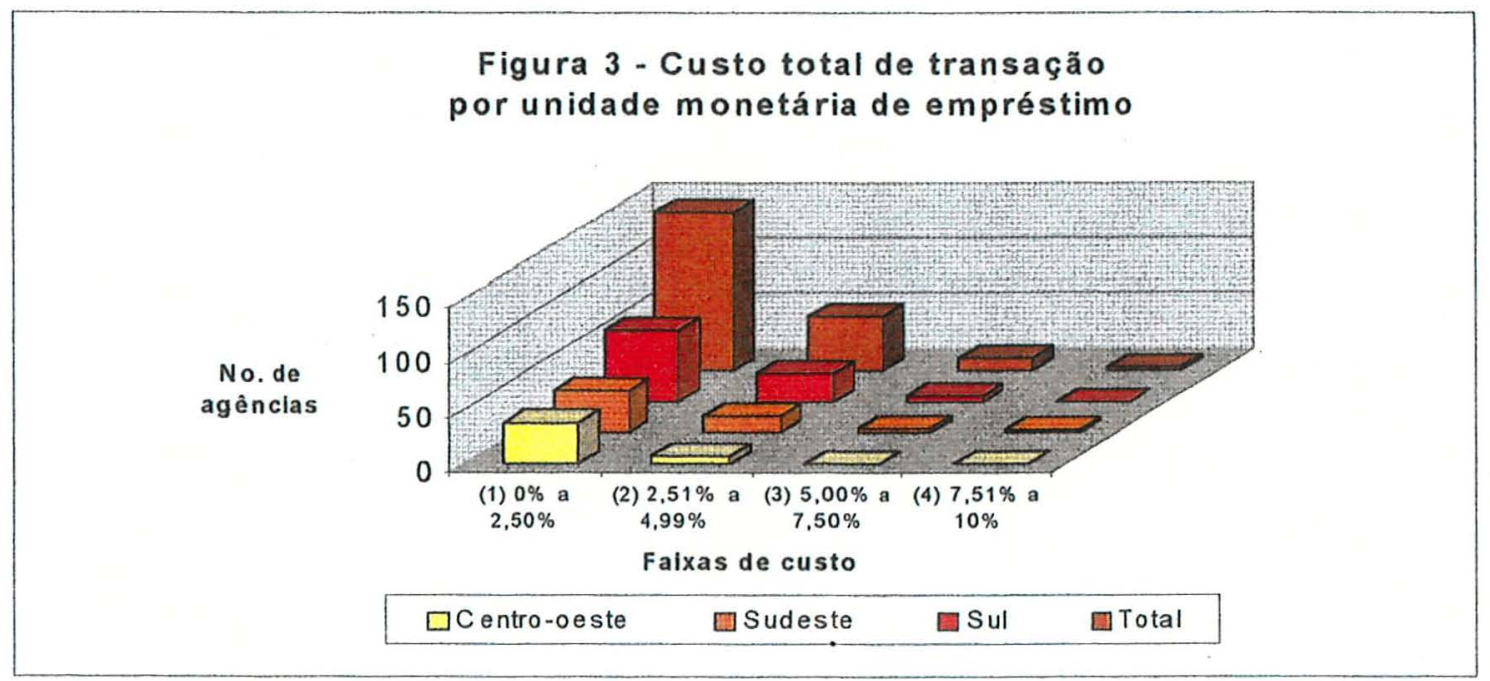

Fonte: Dados da Pesquisa. 
As agências que se encontram nas faixas de custo (2) apresentam um patamar de custos semelhantes ao encontrado nos países desenvolvidos, os quais, segundo MEYER \& CUEVAS (1990), variam entre 3\% e 4\%. Por sua vez, as aqências das faixas de custo (3) e (4) possuem patamar de custos similares aos de países em desenvolvimento com inflação, ou seja, entre $5 \%$ e $10 \%$. Na amostra total, convém salientar que $76,59 \%$ da amostra (157 agências) apresentam custo de transação por unidade monetária abaixo de 3\%, atingindo indices inferiores aos de países desenvolvidos; tal comportamento prevalecendo também nas três sub-regiões analisadas (Centro-oeste - 84,78\% (39 agências); Sudeste $71,43 \%$ (45 agências) e Sul - 76,04\% (73 agências). Este é um indicador do nível de eficiência do banco nas suas operações ativas.

Quanto ao custo de transação por unidade monetária de empréstimo por Região Geográfica (Tabela 9), todas as regiões apresentaram custo unitário médio próximo a 2\%, ou seja, muito reduzido até mesmo em paises desenvolvidos. A região Centro-oeste foi a que apresentou o menor custo unitário de transação de toda a amostra: 0,13\%. Por sua vez, a região sudeste apresentou o maior custo (9,35\%), muito próximo ao limite superior das taxas observadas em vários países em desenvolvimento. Outro aspecto curioso foi que esta região apresenta também a maior variação entre os limites mínimo e máximo. Na região Sul, o valor médio é o mais próximo do observado na amostra total. 
Tabela 9 - Valores míaimo, médio e máximo do custo de transação por unidade monetária de empréstimo na amostra das agências do banco, segundo as Regiões Geográficas.

\begin{tabular}{lcccc}
\hline \multirow{2}{*}{ Amostra } & \multirow{2}{*}{$\begin{array}{c}\text { No. de } \\
\text { agências }\end{array}$} & \multicolumn{2}{c}{ Custo de transação por unidade monetária } \\
\cline { 3 - 5 } & 205 & $0,13 \%$ & $2,11 \%$ & Mínimo \\
Total & 46 & $0,13 \%$ & $1,60 \%$ & $9,35 \%$ \\
Centro-oeste & 63 & $0,27 \%$ & $2,47 \%$ & $5,70 \%$ \\
Sudeste & 96 & $0,29 \%$ & $2,12 \%$ & $9,35 \%$ \\
Sul & & &
\end{tabular}

Fonte: Dados da Pesquisa.

Assim sendo, com relação ao parâmetro custo de transação por unidade monetária de empréstimo, a maioria das agências teria bom desempenho.

Entretanto, como as estatísticas de custo por agência do banco em análise não estão suficientemente desagregadas, não é possivel realizar estudo mais objetivo dos componentes e da estrutura do custo total, principalmente do custo administrativo.

A Tabela 10 e Figura 4 demonstram as faixas de custo total de transação na amostra de agências do banco, segundo as Regiões Geográficas, no período de novembro/94 a julho/95.

Pode-se observar que grande parte das agências possui um baixo custo operacional: cerca de R\$ 300.000,00 no período de novembro/94 a julho/95. Na amostra total, 157 agências apresentaram custo total de transação igual ou inferior a este valor, o que representa 76,59응 a amostra. 
Tabela 10 - Faixas de custo total de transação na amostra de agências do banco, segundo as Regiões Geográficas, novembro/94 a julho/95.

\begin{tabular}{|c|c|c|c|c|}
\hline \multirow[t]{2}{*}{ Faixas de Custo } & \multicolumn{4}{|c|}{ Número de Agências da Amostra } \\
\hline & Total & Centro-oeste & Sudeste & Sul \\
\hline (1) até RS 100.000,00 & 39 & 6 & 6 & 27 \\
\hline (2) $\mathrm{R} \$ 100.000,01 \mathrm{a}$ & 71 & 18 & 23 & 30 \\
\hline$R \$ 200.000,00$ & & & & \\
\hline (3) RS 200.000,01 a & 47 & 15 & 18 & 14 \\
\hline$R \$ 300.000,00$ & & & & \\
\hline (4) RS $300.000,01 \mathrm{a}$ & 17 & 4 & 6 & 7 \\
\hline R\$ $400.000,00$ & & & & \\
\hline (5) $\mathrm{R} \$ 400.000,01 \mathrm{a}$ & 10 & 1 & 4 & 5 \\
\hline $\mathrm{R} \$ 500.000,00$ & & & & \\
\hline (6) $\mathrm{R} \$ 500.000,01 \mathrm{a}$ & 11 & 1 & 4 & 6 \\
\hline $\mathrm{R} \$ 600.000,00$ & & & & \\
\hline (7) R\$ $600.000,01 \mathrm{a}$ & 1 & 0 & 0 & 1 \\
\hline$R \$ 700.000,00$ & & & & \\
\hline (8) R\$ $700.000,01 \mathrm{a}$ & 2 & 1 & 0 & 1 \\
\hline R\$ $800.000,00$ & & & & \\
\hline (9) R\$ $800.000,01 \mathrm{a}$ & 1 & 0 & 0 & 1 \\
\hline$R \$ 900.000,00$ & & & & \\
\hline (10) $\operatorname{R\$ } 900.000,01 \mathrm{a}$ & 1 & 0 & 0 & 1 \\
\hline$R \$ 1.000 .000,00$ & & & & \\
\hline$(11)>\operatorname{R} \$ 1.000 .000,00$ & 5 & 0 & 2 & 3 \\
\hline
\end{tabular}

Fonte: Dados da Pesquisa. 


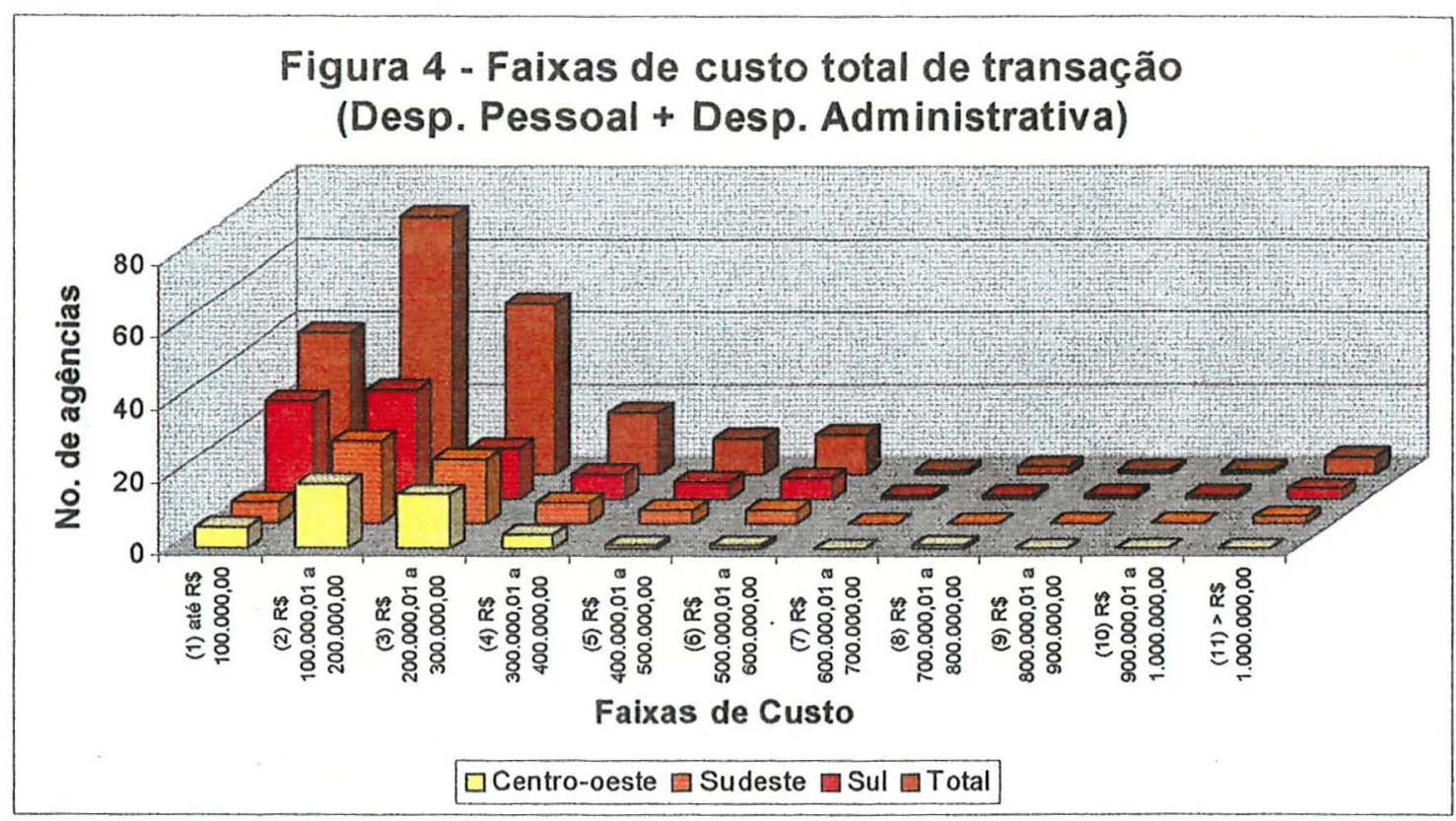

Fonte: Dados da Pesquisa.

Na Tabela 11, observa-se que o valor do custo operacional médio das 205 agências é relativamente baixo (R\$ 247.417,50). Para a região Centro-oeste, obtém-se valor médio ainda menor (R\$ 212.655,51). A região Sudeste é a que apresenta maior custo operacional médio ( $R \$ 266.703,46)$.

É importante notar que entre as agências da amostra há uma grande a variação entre os valores mínimos e máximos. 
Tabela 11 - Valores mínimo, médio e máximo de custo total de transação na amostra de agências do banco, segundo as Regiões Geográficas, novembro/94 a julho/95.

\begin{tabular}{lccccc}
\hline Amostra & No. de & \multicolumn{2}{c}{ Custo total de transação (R\$̧) } \\
\cline { 3 - 5 } & agências & Mínimo & Médio & Máximo \\
\hline Total & 205 & $49.720,65$ & $247.417,50$ & $1.575 .723,08$ \\
Centro-oeste & 46 & $68.388,32$ & $212.655,51$ & $753.577,99$ \\
Sudeste & 63 & $55.405,74$ & $266.703,46$ & $1.575 .723,08$ \\
Sul & 96 & $49.720,65$ & $251.417,87$ & $1.526 .268,82$ \\
\hline
\end{tabular}

Fonte: Dados da Pesquisa.

Para analisar o efeito do tamanho da carteira de crédito rural sobre o custo de transação do banco, são utilizados dois indicadores: volume total de recursos aplicados e número de contratos em cada agência. Com o propósito de examinar o primeiro indicador, as agências são classificadas em nove categorias, conforme a Tabela 12 e Figura 5 .

Da análise da Tabela 12, pode-se constatar que a maioria das agências apresenta um volume total de recursos aplicados em crédito rural bastante expressivo, superior a um milhão de reais. Na amostra total, há 157 agências nesta situação, correspondendo a 76,58\% da amostra; nas demais regiões foram também encontrados valọ̣es percentuais elevados: Centro-oeste - 41 agências $189,13 \%$ da subamostra); Sudeste - 43 agências $(68,25 \%$ e Sul - 73 agências $(76,04 \%)$. 
Tabela 12 - Medidas de tamanho da carteira de crédito rural na amostra de agências do banco, segundo as Regiões Geográficas, novembro/94 a julho/95.

\begin{tabular}{|c|c|c|c|c|}
\hline \multirow{2}{*}{$\begin{array}{l}\text { Volume Total Aplicado } \\
\text { em Crédito Rural }\end{array}$} & \multicolumn{4}{|c|}{ Número de Agências da Amostra } \\
\hline & Total & Centro-oeste & Sudeste & Sul \\
\hline$(1)<\mathrm{R} \$ 300.000,00$ & 16 & 2 & 9 & 5 \\
\hline (2) $\mathrm{R} \$ 300.000,00 \mathrm{a}$ & 12 & 1 & 4 & 7 \\
\hline$R \$ 500.000,00$ & & & & \\
\hline (3) $\mathrm{RS} 500.000,01 \mathrm{a}$ & 20 & 2 & 7 & 11 \\
\hline $\mathrm{R} S 1.000 .000,00$ & & & & \\
\hline $\begin{array}{l}\text { (4) } \mathrm{R} \$ 1.000 .000,01 \mathrm{a} \\
\mathrm{R} \$ 3.000 .000,00\end{array}$ & 52 & 10 & 15 & 27 \\
\hline $\begin{array}{l}\text { (5) } \operatorname{RS} 3.000 .000,01 \mathrm{a} \\
\operatorname{R} \$ 10.000 .000,00\end{array}$ & 56 & 13 & 14 & 29 \\
\hline $\begin{array}{l}\text { (6) } R \$ 10.000 .000,01 \mathrm{a} \\
\operatorname{R} 25.000 .000,00\end{array}$ & 29 & 11 & 9 & 9 \\
\hline $\begin{array}{l}\text { (7) } R \$ 25.000 .000 ; 01 \mathrm{a} \\
\mathrm{R} \$ 50.000 .000,00\end{array}$ & 16 & 5 & 5 & 6 \\
\hline $\begin{array}{l}\text { (8) } R \$ 50.000 .000,01 \text { a } \\
R \$ 75.000 .000,00\end{array}$ & 3 & 2 & 0 & 1 \\
\hline $\begin{array}{l}\text { (9) } \mathrm{R} \$ 75.000 .000,01 \mathrm{a} \\
\mathrm{R} \$ 100.000 .000,00\end{array}$ & 1 & 0 & 0 & 1 \\
\hline
\end{tabular}

Fonte: Dados da Pesquisa. 


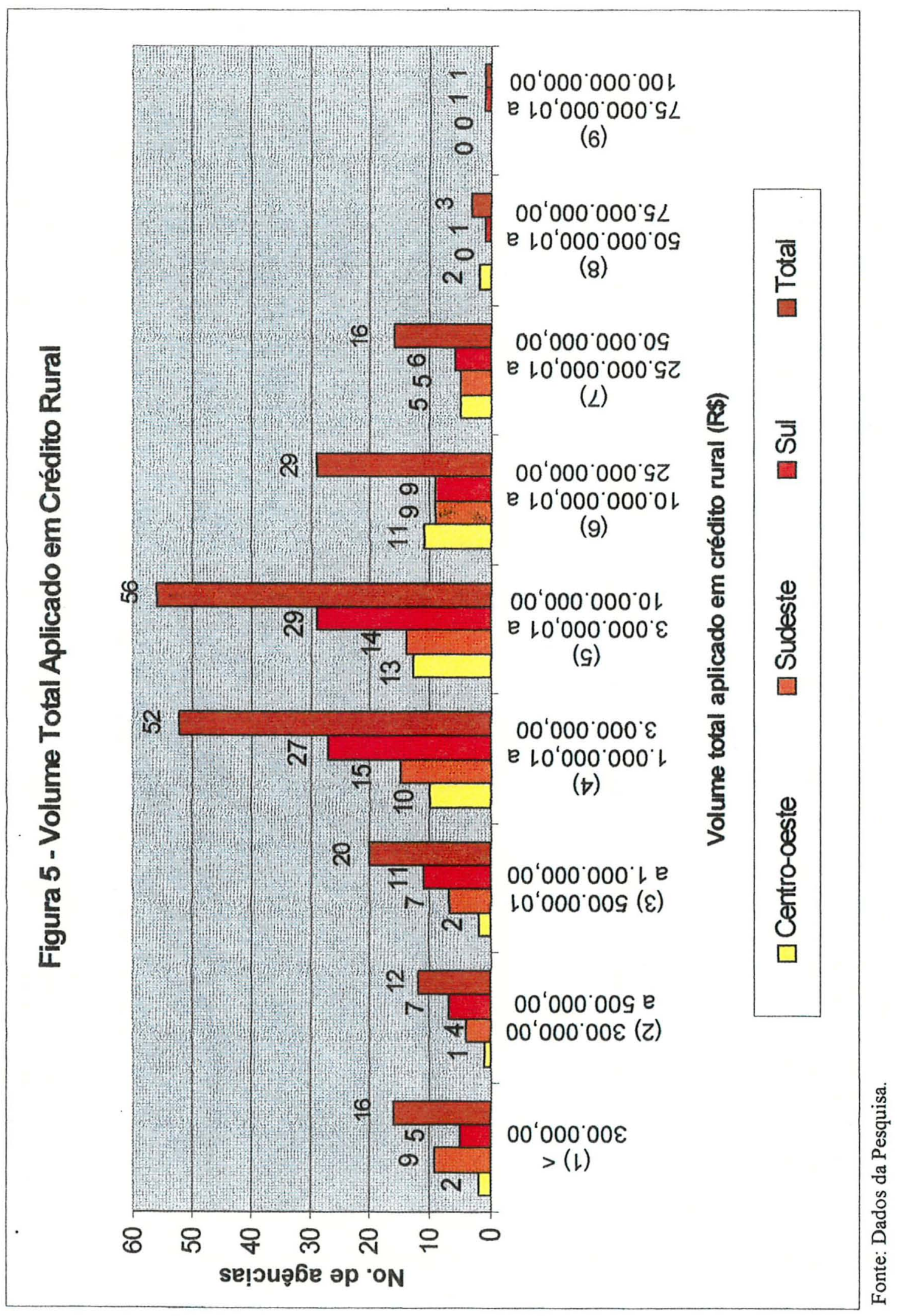


A Tabela 13 mostra que a média de recursos aplicados em crédito rural pelas agências da amostra gira ao redor de 8,3 milhões de reais. Aspecto a destacar é que a região Sul apresenta, simultaneamente, a agência de menor e de maior volume de recursos aplicados em crédito rural.

Tabela 13 - Valores mínimo, médio e máximo do Volume Total Aplicado em Crédito Rural na amostra de agências do banco, segundo as Regiões Geográficas, novembro/94 a julho/95.

\begin{tabular}{lcccc}
\hline Amostra & No. de & \multicolumn{2}{c}{ Volume Total Aplicado em Crédito Rural(R) } \\
\cline { 3 - 5 } & agências & Mínimo & Médio & Máximo \\
\hline Total & 205 & $29.136,00$ & $8.308 .553,89$ & $97.327 .372,92$ \\
Centro-oeste & 46 & $88.418,19$ & $11.859 .449,98$ & $73.340 .153,94$ \\
Sudeste & 63 & $40.689,78$ & $6.420 .667,79$ & $39.425 .646,25$ \\
Sul & 96 & $29.136,00$ & $7.846 .008,10$ & $97.327 .372,92$ \\
\hline
\end{tabular}

Fonte: Dados da Pesquisa.

Ainda para a análise do tamanho da carteira de crédito rural, as agências foram divididas em função do número de contratos em cinco faixas de grandeza, conforme a Tabela 14 e Figura 6. 
Tabela 14 - Medidas de tamanho da carteira de crédito rural na amostra de agências do banco, segundo as Regiões Geográficas, novembro/94 a julho/95.

\begin{tabular}{lccccc}
\hline Número de Contratos & \multicolumn{2}{c}{ Número de Agências da Amostra } \\
\cline { 2 - 5 } & Total & Centro-oeste & Sudeste & Sul \\
\hline (1) $\leq 50$ & 93 & 19 & 38 & 36 \\
(2) 51 a 100 & 37 & 4 & 12 & 21 \\
(3) 101 a 500 & 69 & 23 & 12 & 34 \\
(4) 501 a 1.000 & 5 & 0 & 1 & 4 \\
(5) $>1.000$ & 1 & 0 & 0 & 1 \\
\hline
\end{tabular}

Fonte: Dados da Pesquisa.

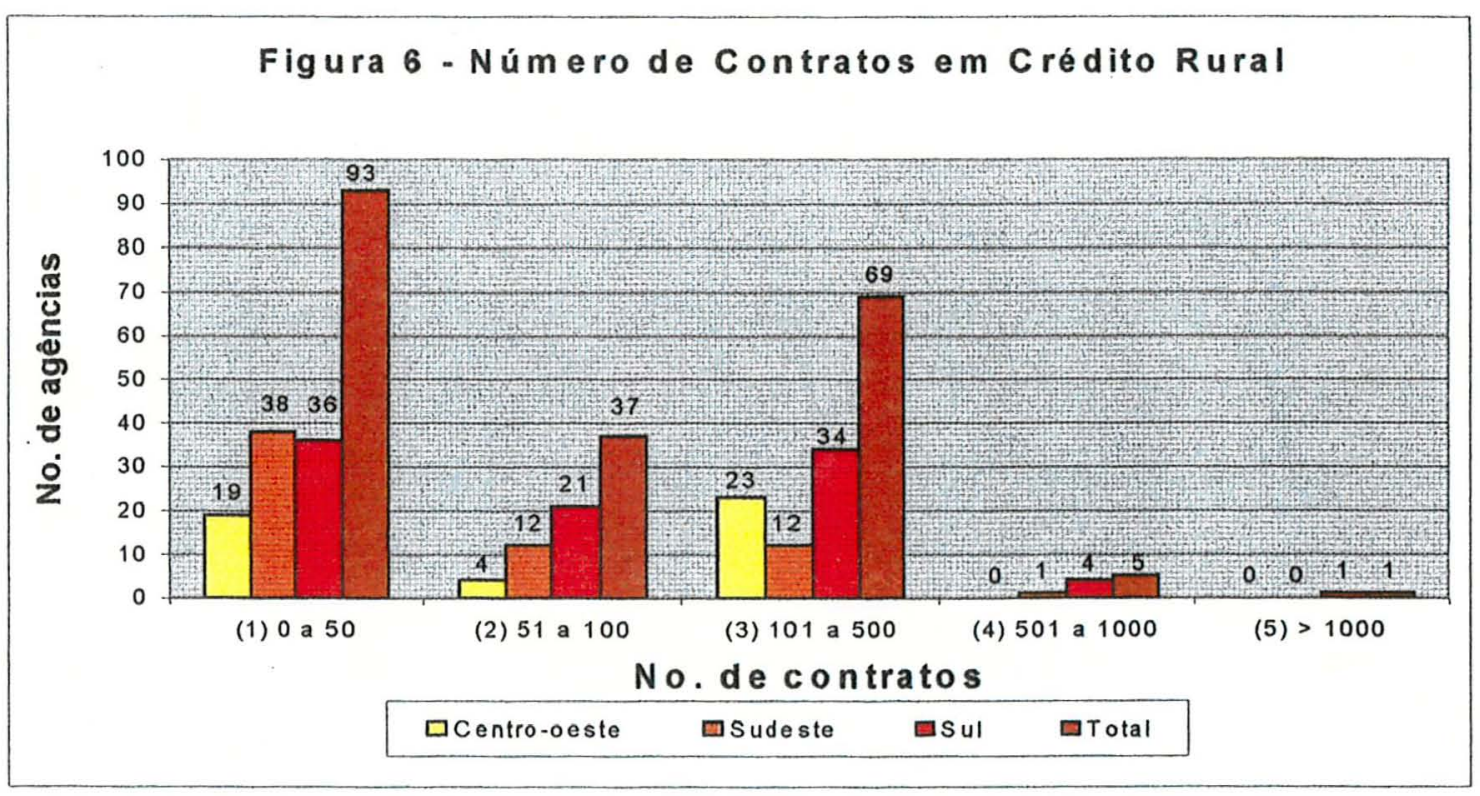

Fonte: Dados da Pesquisa.

Pode-se observar, na Tabela 14, que a maioria das agências $(63,40 \%$ da amostra) opera com um número de contratos de crédito rural, inferior/igual a 100 por agência. Esta constatação associada ao fato de haver uma 
grande concentração de agências operando com um volume expressivo de recursos na carteira agrícola (Tabela 12) indica que, na amostra, as agências trabalham com contratos de elevado valor.

A Tabela 15 mostra que, na amostra total, a média de contratos de crédito rural é de 113 contratos por agência. Há uma grande disparidade entre os valores mínimos e máximos para o número de contratos de crédito rural por agência, sendo a região sul a que apresenta maior variação.

Tabela 15 - Valores mínimo, médio e máximo do número de Contratos em Crédito Rural na amostra de agências do banco, segundo as Regiões Geográficas, novembro/94 a julho/95.

\begin{tabular}{|c|c|c|c|c|}
\hline \multirow[t]{2}{*}{ Amostra } & \multirow{2}{*}{$\begin{array}{c}\text { No. de } \\
\text { agências }\end{array}$} & \multirow{2}{*}{$\frac{\text { Número de }}{\text { Mínimo }}$} & \multirow{2}{*}{$\frac{\text { Contratos em }}{\text { Médio }}$} & \multirow{2}{*}{$\frac{\text { Crédito Rural }}{\text { Máximo }}$} \\
\hline & & & & \\
\hline Total & 205 & 1 & 113 & 1.293 \\
\hline Centro-oeste & 46 & 2 & 119 & 388 \\
\hline Sudeste & 63 & 1 & 74 & 632 \\
\hline Sul & 96 & 1 & 135 & 1.293 \\
\hline
\end{tabular}

Fonte: Dados da Pesquisa.

Analisando, ainda, o valor médio dos contratos de crédito rural como indicador do nível de eficácia na utilização da tecnologia bancária, as agências foram classificadas em sete faixas, conforme a Tabela 16 e Figura 7. 
Tabela 16 - Eficácia no uso da tecnologia bancária no crédito rural na amostra de agências do banco, seguncio as Regiões Geográficas, noveinbro/94 a julho/95.

Valor Médio dos

Contratos de crécito Rural
Número de Agências da Amostra

Total Centro-oeste Sudeste sul

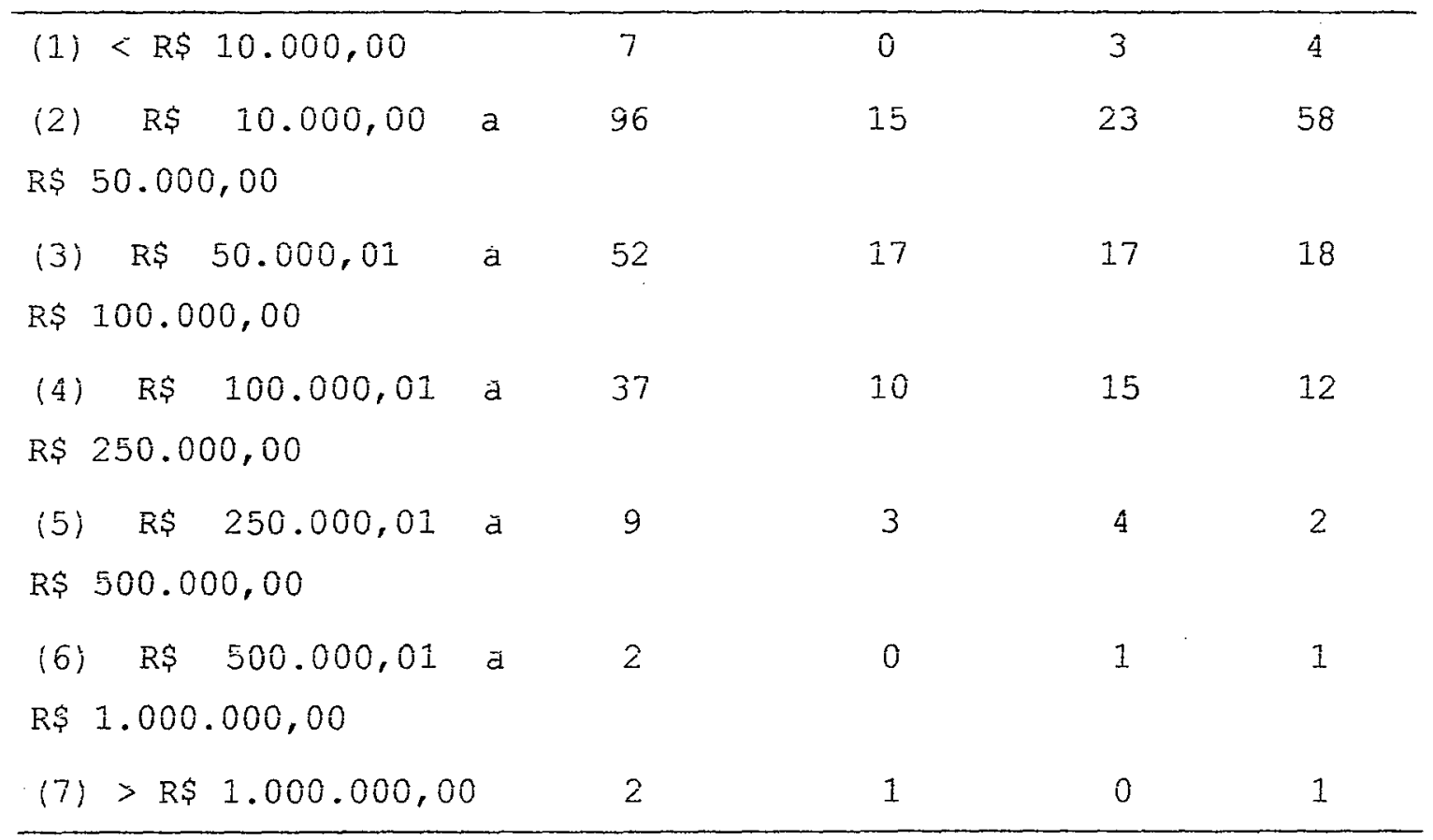

Fonte: Dados da Pesquisa. 


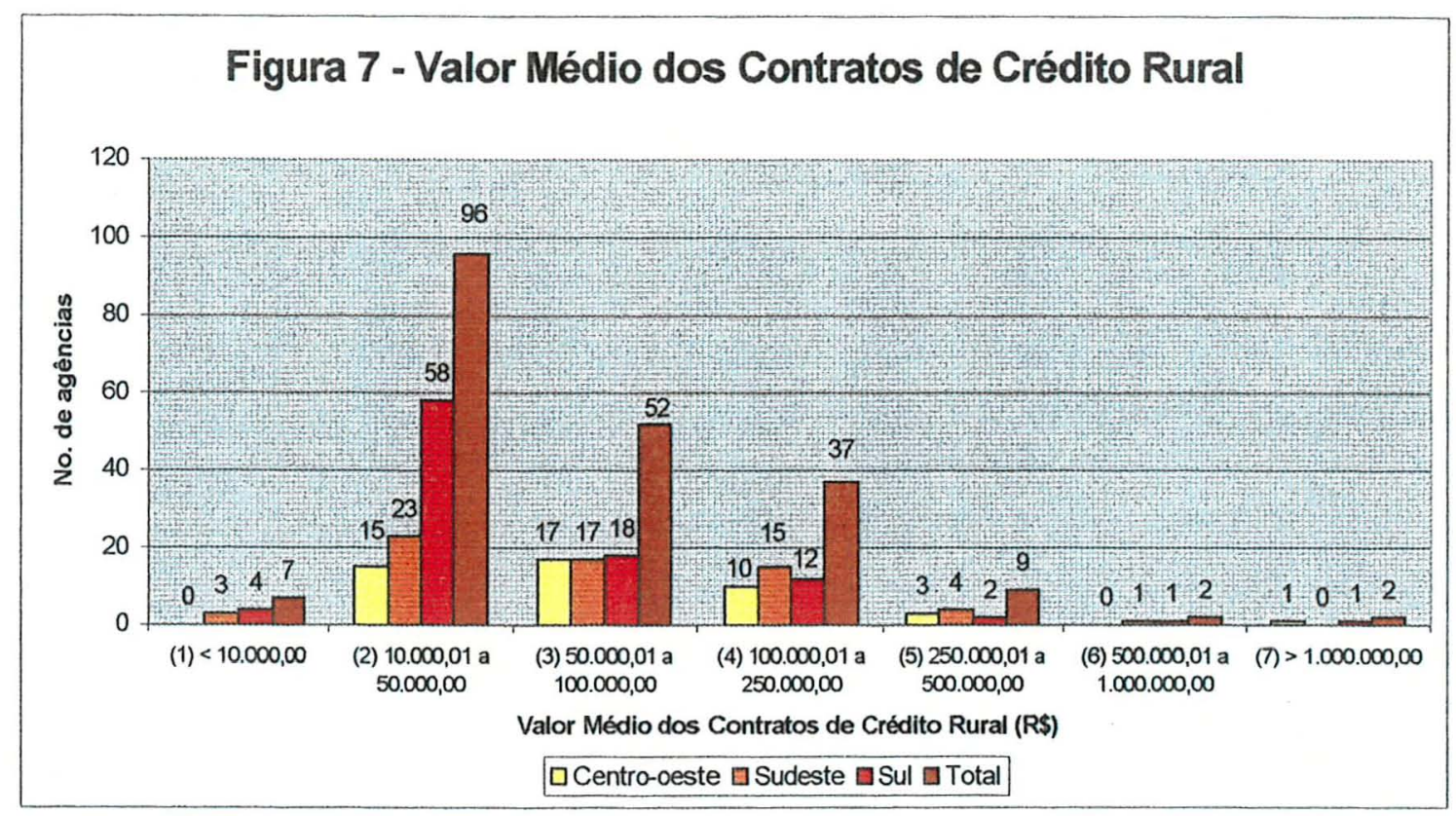

Fonte: Dados da Pesquisa.

Pode-se constatar que boa parte das agências apresenta valores médios bastante elevados nos contratos de crédito rural, ou seja, variando de 10 mil a 250 mil reais por contrato. Há 185 agências nesta situação, correspondendo a 90,24\% da amostra; nas sub-amostras regionais foram também encontrados valores percentuais nesta faixa de valor médio: Centro-oeste - 42 agências $(91,30 \%$ da sub-amostra); Sudeste - 55 agências $(87,30 \%$ e Sul - 88 agências $(91,67 \%)$.

Como ilustram os dados da Tabela 17, há uma grande variação entre os valores médios dos contratos de crédito rural praticados pelas agências da amostra, sendo encontrados valores muito baixos, como por exemplo, na região Sul, uma agência opera com o valor médio da ordem de 1,14 mil reais (o mais baixo da amostra), enquanto no 
Centro-oeste, há uma agência com valor médio dos contrato superior a 2,5 milhões de reais (o mais alto da amostra).

Comparando esses resultados com os apontados por PESSÔA (1996), constata-se que o banco privado em estudo opera com maior valor médio dos contratos de crédito rural, cerca de $104 \mathrm{mil}$ reais, enquanto 62 agências de bancos oficiais operavam, no período de 1990-1993, com contratos de valor médio 9 vezes menor (11 mil reais).

Tabela 17 - Valores mínimo, médio e máximo de eficácia no uso da tecnologia bancária disponível na amostra de agências do banco, segundo as Regiões Geográficas, novembro/94 a julho/95.

\begin{tabular}{lcccc}
\hline Amostra & \multirow{2}{*}{$\begin{array}{c}\text { No. de } \\
\text { agências }\end{array}$} & \multicolumn{2}{c}{ Valor Médio dos Contratos de Crédito Rural (RS) } \\
\cline { 3 - 5 } & 205 & $1.141,43$ & $104.236,19$ & $2.683 .052,09$ \\
\hline Total & 46 & $13.782,57$ & $150.042,24$ & $2.683 .052,09$ \\
Centro-oeste & 63 & $4.521,09$ & $101.117,79$ & $798.494,46$ \\
Sudeste & 96 & $1.141,43$ & $84.333,90$ & $2.339 .418,65$ \\
Sul & & &
\end{tabular}

Fonte: Dados da Pesquisa.

Na Tabela 18 e Figura 8, as agências são avaliadas quanto ao grau de especialização em crédito rural, tomando-se por base a relação entre aplicações em crédito rural e aplicações totais da agência. Como se pode observar, a maior parte das agências (135) opera com grau de especialização que varia de $10 \%$ a $50 \%$; sendo que nesse grupo, 71 agências registram especialização variando entre $31 \%$ e $50 \%$. 
Tabela 18 - Relação entre aplicações em crédito rural e aplicações totais na amostra de agências do banco, segundo as Regiões Geográficas, novembro/94 a julho/95.

\begin{tabular}{lcccc}
\hline Aplicações em Crédito & \multicolumn{2}{c}{ Número de Agências da Amostra } \\
\cline { 2 - 5 } Rural/Aplicações Totais & Total & Centro-oeste & Sudeste & Sul \\
\hline (1) $<10 \%$ & 30 & 4 & 15 & 11 \\
(2) 10 a 30\% & 64 & 10 & 20 & 34 \\
(3) 31 a 50\% & 71 & 19 & 16 & 36 \\
(4) 51 a $80 \%$ & 40 & 13 & 12 & 15 \\
\hline
\end{tabular}

Fonte: Dados da Pesquisa.

\section{Figura 8 - Aplicações em Crédito Rural/Aplicações Totais}

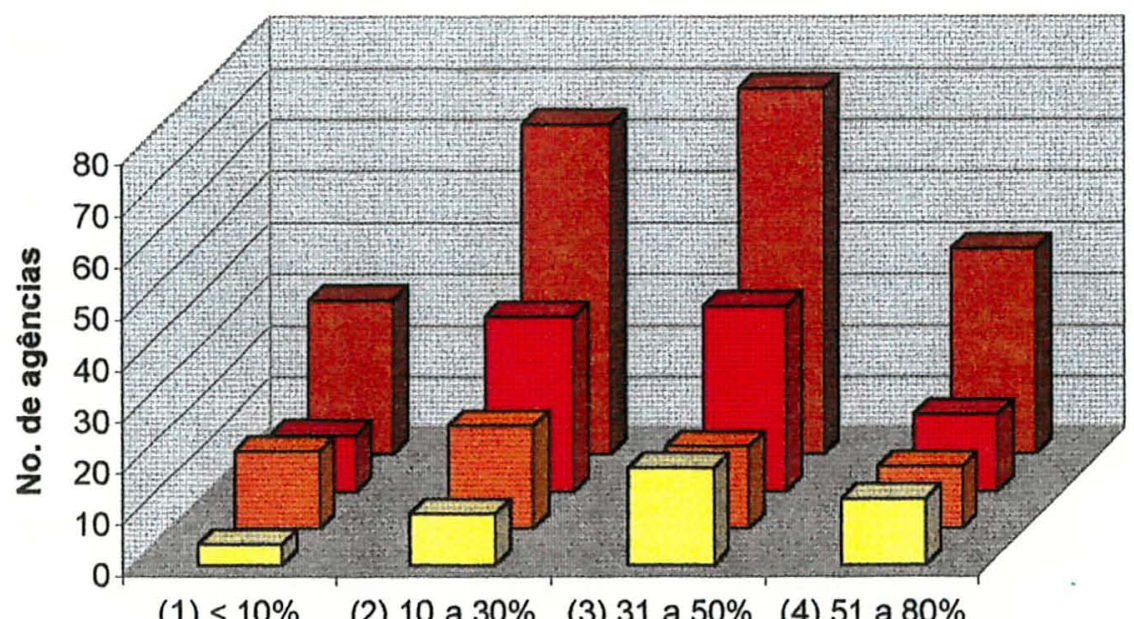

$\begin{array}{llll}(1)<10 \% & \text { (2) } 10 \text { a } 30 \% & \text { (3) } 31 \text { a } 50 \% & \text { (4) } 51 \text { a } 80 \%\end{array}$

Aplicações em crédito rural $/$ aplicações totais

$\square$ Centro-oeste $\square$ Sudeste ( Sul $_{\square}$ Total

Fonte: Dados da Pesquisa. 
Pela Tabela 19, em termos médios, pode-se inferir que as agências pertencentes à região centro-oeste apresentam o maior índice de especialização em crédito rural $(38,40 \%)$, seguindo-se as regiões sul com 32,30\% e Sudeste com 29,04\%.

Tabela 19 - Valores mínimo, médio e máximo da relação entre aplicações em crédito rural e aplicações totais na amostra de agências do banco, segundo as Regiões Geográficas, novembro/94 a julho/95.

\begin{tabular}{lcccc}
\hline Amostra & $\begin{array}{c}\text { No. de } \\
\text { agências }\end{array}$ & $\begin{array}{c}\text { Aplicações em Crédito Rural / } \\
\text { Aplicações Totais da Agência }\end{array}$ \\
\cline { 3 - 5 } & & Mínimo & Médio & Máximo \\
\hline Total & 205 & $0,33 \%$ & $32,67 \%$ & $76,33 \%$ \\
Centro-oeste & 46 & $1,63 \%$ & $38,40 \%$ & $67,86 \%$ \\
Sudeste & 63 & $0,55 \%$ & $29,04 \%$ & $76,33 \%$ \\
Sul & 96 & $0,33 \%$ & $32,30 \%$ & $73,23 \%$ \\
\hline
\end{tabular}

Fonte: Dados da Pesquisa.

Finalmente, é analisado o volume total de recursos aplicados em crédito não-agrícola. Para tanto, as agências são classificadas, na Tabela 20 e Figura 9, em cinco faixas de tamanho. 
Tabela 20 - Faixas de Volume Total Aplicado em Crédito Não-agrícola na amostra de agências do banco, segundo as Regiões Geográficas, novembro/94 a julho/95.

\begin{tabular}{|c|c|c|c|c|}
\hline \multirow{2}{*}{$\begin{array}{l}\text { Volume Total Aplicado } \\
\text { em Crédito Não-agrícola }\end{array}$} & \multicolumn{4}{|c|}{ Número de Agências da Amostra } \\
\hline & Total & Centro-oeste & Sudeste & Sul \\
\hline (1) $>\mathrm{R} \$ 1.000 .000,00 \mathrm{e}$ & 31 & 4 & 10 & 17 \\
\hline$\leq \mathrm{R} \$ 3.000 .000,00$ & & & & \\
\hline (2) $>\mathrm{R} \$ 3.000 .000,00 \mathrm{e}$ & 93 & 22 & 28 & 43 \\
\hline$\leq \mathrm{R} \$ 10.000 .000,00$ & & & & \\
\hline (3) $>\mathrm{R} \$ 10.000 .000,00$ & 58 & 12 & 19 & 27 \\
\hline$e \leq R \$ 25.000 .000,00$ & & & & \\
\hline$(4)>\mathrm{R} \$ 25.000 .000,00$ & 21 & 8 & 5 & 8 \\
\hline$e \leq R \$ 50.000 .000,00$ & & & & \\
\hline (5) $>\mathrm{R} \$ 50.000 .000,00$ & 2 & 0 & 1 & 1 \\
\hline
\end{tabular}

Fonte: Dados da Pesquisa.

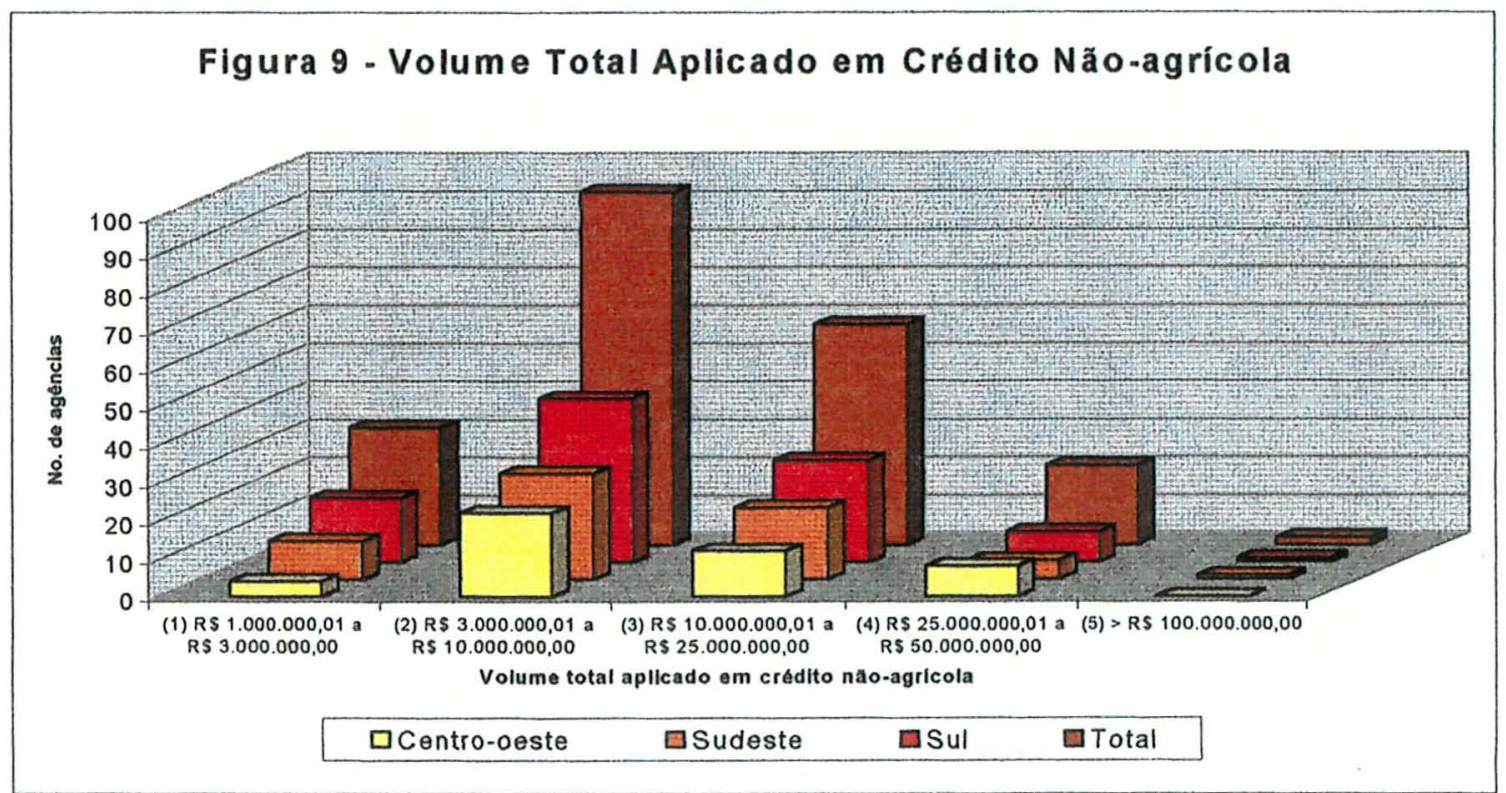

Fonte: Dados da Pesquisa. 
Observa-se que na amostra total a maioria das agências analisadas (151) apresenta um elevado volume total de recursos aplicados em crédito não-agrícola, concentrando-se na faixa de 3 milhões a 25 milhões de reais/agência. Nas sub-amostras regionais, nesse mesmo intervalo de operações não-agrícolas são encontrados os seguintes valores: Centro-oeste - 34 agências $(73,91 \%$ da sub-amostra); Sudeste - 47 agências $(74,60 \%)$ e, Sul - 70 agências $(72,92$ \% $)$.

Tabela 21 - Valores mínimo, médio e máximo do Volume Total Aplicado em Crédito Não-agrícola na amostra de agências do banco, segundo as Regiões Geográficas, novembro/94 a julho/95.

\begin{tabular}{lcccc}
\hline Amostra & $\begin{array}{c}\text { No. de } \\
\text { agências }\end{array}$ & \multicolumn{4}{c}{$\begin{array}{c}\text { Volume Aplicado } \\
\end{array}$} & & Mínimo & Médio & Máximo \\
\cline { 2 - 5 } & 205 & $1.067 .602,98$ & $11.889 .780,09$ & $109.550 .357,89$ \\
\hline Total & 46 & $1.283 .021,09$ & $13.023 .146,04$ & $40.945 .152,09$ \\
Centro- & & & & \\
oeste & 63 & $1.165 .682,77$ & $12.635 .917,09$ & $103.448 .221,60$ \\
Sudeste & 96 & $1.067 .602,98$ & $10.857 .056,51$ & $109.550 .357,89$ \\
\hline
\end{tabular}

Fonte: Dados da Pesquisa.

Analisando a Tabela 21, constata-se que a média de recursos aplicados em crédito não-agrícola pelas agências do banco é de aproximadamente 11 milhões de reais. Este valor é $43 \%$ superior ao valor médio das aplicações em 
crédito rural. Entretanto, quando se comparam os valores mínimos e máximos das duas carteiras, nota-se uma nítida preferência do banco para aplicações não-agrícolas.

\section{2. - Análise econométrica}

São ajustados dois modelos econométricos de regressão múltipla, linear nos logarítmos, visando estimar relações econométricas entre custos de transação do banco e parâmetros inerentes às carteiras de crédito rural e escala de operações ativas do banco por agência.

o primeiro modelo mede o custo total de transação e o segundo modelo, o custo total de transação por unidade monetária de empréstimo. No Apêndice 2, são apresentadas as matrizes de correlação dos dois modelos. O programa estatístico utilizado foi o SAS versão 6.04 .

$\mathrm{Na}$ tabela 22, aparecem as estatísticas do primeiro modelo econométrico (Modelo I) relacionando o custo total de transação das agências bancárias e as três variáveis independentes especificadas no modelo econômico.

$\mathrm{Na}$ amostra total, as variáveis independentes do Modelo I podem explicar 59,9\% das variações observadas no custo total de transação $\left(Y_{1}\right)$, o que constitui bom nível de explicação. 


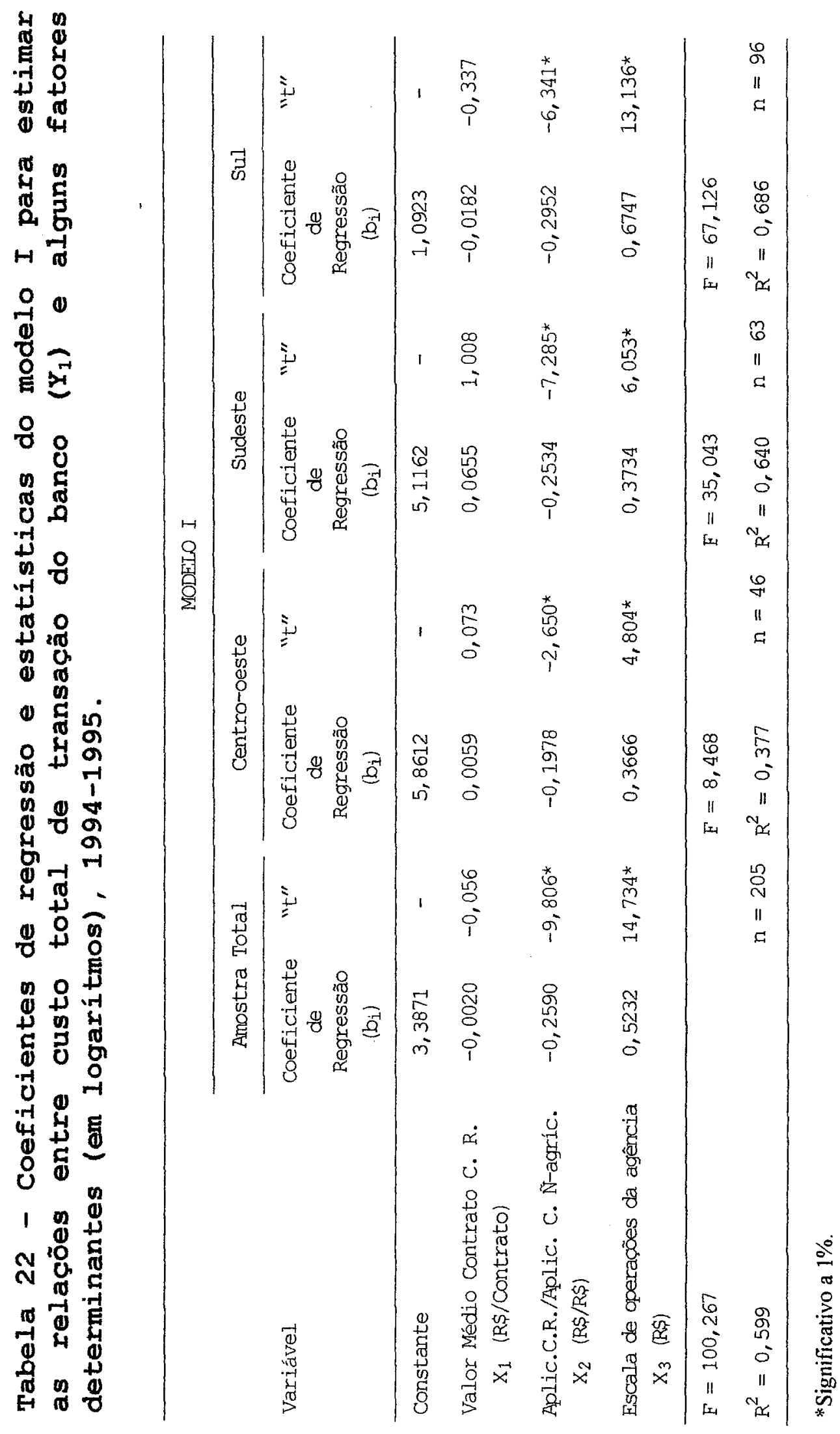


As estimativas dos coeficientes (elasticidades) das variáveis $\mathrm{X}_{2}$ (especialização em crédito rural) e $\mathrm{X}_{3}$ (escala de operações ativas) mostram-se significativas ao nível de $1 \%$ de probabilidade. A variável $x_{1}$ (valor médio dos contratos de crédito rural) não é significativa, embora tenha o sinal esperado.

Essas estimativas sugerem que coeteris paribus: : (a) o aumento de $10 \%$ na relação aplicações em crédito rural/aplicações não-agrícolas da agência tende a diminuir em 2,59\% o custo total de transação; $e$, (b) o aumento de 10\% no volume total de aplicações da agência tende a aumentar em 5,23\% o custo de transação.

$\mathrm{Na}$ sub-amostra da região Centro-oeste, as variáveis independentes podem explicar apenas 37,7\% das variações observadas no custo de transação. Os coeficientes estimados para as variáveis $\mathrm{X}_{2}$ (especialização em crédito rural) e $x_{3}$ (escala de operações) são significativos a $1 \%$ de probabilidade; o coeficiente da variável valor médio por contrato de crédito rural $\left(X_{1}\right)$ segue não significativo.

$\mathrm{Na}$ sub-amostra do Sudeste, o Modelo I pode explicar $64,0 \%$ das variações do custo. As variáveis $\mathrm{X}_{2}$ e $\mathrm{x}_{3}$ permanecem significativas ao nível de 1 몽, enquanto $X_{1}$ não é significativa. Na sub-amostra da região Sul, as variáveis independentes podem explicar $68,6 \%$ das variações do custo. E como nos casos anteriores, apenas os coeficientes das variáveis $x_{2}$ e $x_{3}$ são significativos ao nível de $1 \%$ de probabilidade.

Analisando os sinais dos coeficientes estimados pelo modelo de regressão da amostra total, observa-se que os mesmos são coerentes com as especificações propostas no 
modelo econômico. Por exemplo: a) o sinal negativo do coeficiente da variável $\mathrm{x}_{2}$ sugere que 0 banco, como um todo, estaria utilizando melhor os seus recursos materiais e humanos quando aumenta a proporção de aplicações em crédito rural (de demanda sazonal); b) o sinal positivo do coeficiente da variável $X_{3}$ indica que aumentos na escala de operações ativas (empréstimos totais) determina aumento no custo total; e, c) o sinal negativo do coeficiente de $\mathrm{x}_{1}$, na amostra e na sub-amostra da Região Sul, foi também previsto pelo modelo econômico, embora não apresente significância estatística.

Na tabela 23, a seguir, são apresentados os resultados do segundo modelo econométrico (Modelo II), relacionando o custo de transação por unidade monetária de empréstimos do banco e as mesmas variáveis independentes $\left(x_{1}, x_{2}, e x_{3}\right)$.

$\mathrm{Na}$ amostra total do banco, as variáveis independentes podem explicar $71,1 \%$ das variações observadas no custo de transação por unidade monetária de empréstimos, - que constitui maior nível de explicação em relação ao Modelo I.

Os coeficientes das variáveis $\mathrm{X}_{2}$ (especialização em crédito rural) e $x_{3}$ (escala de operações) mostram-se significativos ao nível de $1 \%$ de probabilidade; 0 coeficiente estimado para a variável $x_{1}$ (valor médio dos contratos de crédito rural) permanece não significativo. 


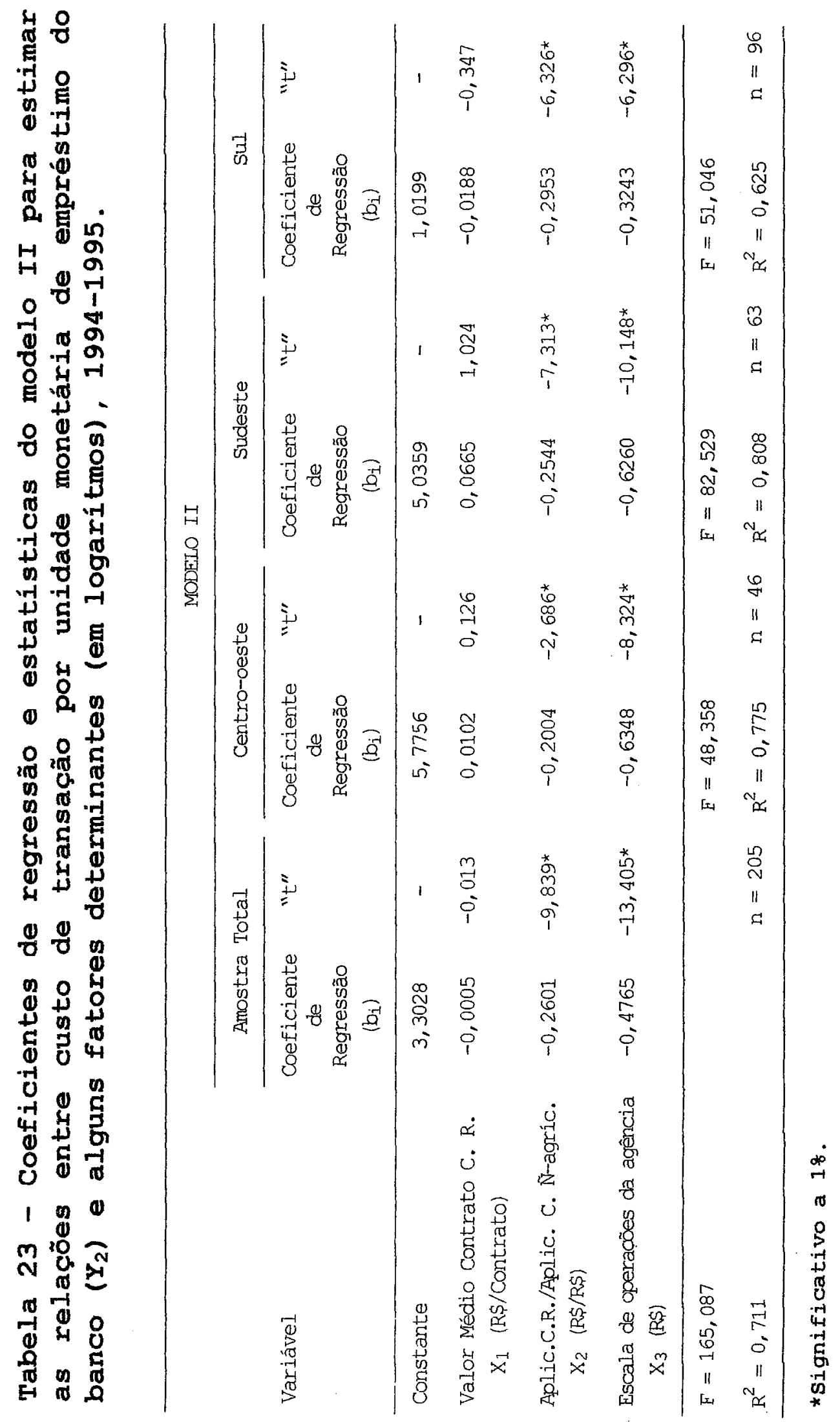


Essas estimativas indicam que coeteris paribus: (a) um aumento de $10 \%$ na relação aplicações em crédito rural/aplicaçôes não-agrícolas da agência tende a reduzir em 2,60\% o custo total de transação por unidade monetária de empréstimos; e, (b) um aumento de 10\% no volume total de operações ativas da agência tende a reduzir em 4,76: 0 custo de transação por unidade monetária de empréstimos.

$\mathrm{Na}$ sub-amostra da região Centro-oeste, as variáveis independentes do modelo podem explicar 77,5\% das variações observadas em $Y_{2}$. Os coeficientes das variáveis $X_{2}$ e $\mathrm{X}_{3}$ mostram-se significativos ao nível de $1 \%$ de probabilidade.

$\mathrm{Na}$ sub-amostra do sudeste, as variáveis independentes podem explicar $80,8 \%$ das variações de $Y_{2}$. Os coeficientes estimados para as variáveis $X_{2} \quad e \quad X_{3}$ são significativos ao nível de 1 응 de probabilidade. Trata-se de um ajustamento com elevado poder explicativo.

$\mathrm{Na}$ sub-amostra da região Sul, tais variáveis independentes podem explicar $62,5 \%$ das variações na variável independente. Neste caso, também, os coeficientes das variáveis $X_{2}$ e $X_{3}$ foram significativas ao nível de $1 \%$

Sobre a estabilidade dos coeficientes de regressão (elasticidades) do modelo II, pode-se inferir que: a) o valor médio dos contratos de crédito rural $\left(\mathrm{X}_{1}\right)$ apresenta sinal negativo na amostra total e na sub-amostra da Região Sul, de acordo com o esperado; b) para o grau de especialização em crédito rural $\left(X_{2}\right)$ obteve-se sinal negativo em todas as regiões; e, c) o volume total aplicado em crédito rural e não-agrícola $\left(\mathrm{X}_{3}\right)$ apresenta sinal 
negativo para todas as regiões, condizente, portanto, com o esperado.

Pode-se considerar que o tamanho da carteira de empréstimos e o grau de especialização da agêncja em operações' de crédito rural são os fatores que mais fortemente influenciam os custos de transação do banco em estudo. O valor médio dos contratos não registra influência significativa sobre os custos de transação.

Do confronto dos resultados obtidos nos dois modelos, pode-se considerar que o modelo II é o melhor ajustado, pois apresenta uniformidade nos sinais, na magnitude dos coeficientes de regressão e maior possibilidade de explicação.

Convém salientar também que, enquanto no Modelo I, a variável representativa do efeito-escala $\left(\mathrm{X}_{3}\right)$ tem efeito positivo sobre o custo total de transação, no Modelo II, afeta negativamente o custo por unidade monetária de empréstimos. A interpretação econômica desses resultados é de que variações positivas no custo, determinadas por $x_{3}$, são menos que proporcionais ao aumento da escala de operações ativas das agências do banco. Daí, resultando o sinal negativo de $x_{3}$ no Modelo II, em que o custo é medido na forma de custo total médio. 


\section{6 - CONCLUSÕES}

Através da análise qualitativa dos dados pode-se concluir que, no crédito rural, o banco empresta volumes expressivos, quando comparados com os resultados encontrados em pesquisas sobre bancos oficiais.

A análise econométrica permite concluir que: a) maior especialização em crédito rural das agências do banco possibilita, com melhor aproveitamento dos recursos disponíveis, redução no custo total de transação; b) aumentando o tamanho da carteira de empréstimos, o custo total aumenta menos que proporcionalmente ao aumento da escala de operações das agências do banco; e, c) em função disso, o custo total de transação por real emprestado diminui quando se aumenta a escala de operações.

As estimativas de custo de transação das agências do banco indicam que o mesmo é relativamente baixo. Muitas das agências apresentaram custos inferiores aos níveis estimados em países de alta renda.

Apesar dessa conclusão ser favorável em termos de eficiência média, existe grande variação de custo entre as agências de uma dada região, bem como entre as regiões em 
que o banco opera. Com efeito, cerca de 30\% das agências da amostra operam com custo total de transação que varia entre 2,5\% e 10\% por unidade monetária de empréstimos agrícolas e não-agrícolas.

Não há indicação aparente de racionamento de crédito rural pelo banco. Ao contrário do que foi evidenciado em pesquisas sobre bancos oficiais, o banco privado em estudo revela que o tamanho da carteira de crédito rural é significativamente maior. Nos bancos oficiais, somente $27 \%$ das agências apresentavam, no período de 1990-1993, volume total aplicado em crédito rural superior a um milhão de reais, enquanto no presente estudo, tal proporção é superior a $76 \%$.

Embora, o valor médio por contrato e o volume de recursos aplicados em crédito rural sejam maiores do que nos bancos oficiais, os resultados desta pesquisa indicam que, como esperado, o banco privado oferece volume maior de recursos ao setor não-agrícola. Isto significa que suas operações ativas são diversificadas.

$\mathrm{Na}$ atual conjuntura, é fundamental que os bancos estruturem suas carteiras agrícolas e não-agrícolas, implantando sistemas de controle de custos. A julgar pelas estatísticas utilizadas neste estudo, não existe um acompanhamento objetivo dos parâmetros de eficiência alocativa dos diversos serviços/produtos oferecidos pelo banco, inclusive na carteira de crédito rural.

o presente estudo de caso, analisando 205 agências de um banco comercial em 3 regiões geográficas do país (Centro-oeste, Sudeste e sul), é uma primeira avaliação econômica da atual situação dos custos de 
transação dos bancos privados no Brasil. Outros estudos semelhantes permitirão aos bancos obter conhecimento mais aprofundado da sua real estrutura de custos de transação. Por outro lado, aos formuladores de políticas monetária e agrícola, futuras pesquisas sobre custos bancários poderão ser muito úteis na avaliação das possibilidades de intervenção no sistema financeiro. 


\section{REFERÊNCIAS BIBLIOGRÁFICAS}

ADAMS, D.W.; NEHMAN, G.I. Borrowing costs and the demand for rural credit. The Journal of Development Studies, v.15, p.165-176, 1979.

ADAMS, D.W. El enigma de proyetos de créditos exitosos en mercados financieros fracasados. In: ADAMS, D.W.; GONZÁLEZ VEGA, C.; VON PISCHKE, J.D. Credito agricola $\mathbf{y}$ desarrollo rural: la nueva vision. Columbus: Ohio State University, 1987b. p.40-56.

ADAMS, D.W. Recent performance of rural financial markets. In: HOWELL, John (Ed.) Borrowers and lenders; rural financial markets in developing countries. Londres: Overseas Development Institute, 1980.

ADAMS, D.W. Son los argumentos en favor del credito agricola barato validos? In: ADAMS, D.W.; GONZÁLEZ VEGA, C.; VON PISCHKE, J.D. Credito agricola $y$ desarrollo rural: la nueva vision. Columbus: Ohio State University, 1987a. p.87-101. 
ADAMS, D.W. Transaction costs in decentralized rural financial markets. Occasional Paper, n.2093, 1994.

ADAMS, D.W.; ROMERO, A.P. Prestamos a grupos de pobres rurales en la Republica Dominicana: una innovacion detenida. In: ADAMS, D.W.; GONZÁLEZ VEGA, C.; VON PISCHKE, J.D. Credito agricola $\mathbf{Y}$ desarrolio rural: la nueva vision: Columbus: Ohio State University, 1987. p. 319-330.

ARAÚJO, P.E.C.; ALMEIDA, A. Financiamento da agricultura: evolução e perspectivas. Preços Agricolas, n.126, p.3-8, Abril 1997.

ARAÚJO, P.E.C.; ALMEIDA, A. Financiamento rural nos mercados informais. In: SEMINÁRIO NACIONAL: AS DIFÍCEIS OPÇÕES DO FINANCIAMENTO RURAL, Belo Horizonte, MG, 1992. Anais . Belo Horizonte, MG, 1992. p.1-15.

ARAÚJO, U.M. Assimetria de informação no crédito rural: Aspectos teóricos e um modelo para classificação do risco dos créditos concedidos a cooperativas agropecuárias. Piracicaba, 1996. 81p. Tese (Doutorado) - Escola Superior de Agricultura Luiz de Queiroz, Universidade de São paulo.

BANCO CENTRAL DO BRASIL. Departamento de Cadastro e Informações. Rede de agências por município. Brasilia, 1998 .

BANCO CENTRAL DO BRASII. Sistema de Informações. cosIF: Consolidação Contábil das Instituições do sistema Financeiro Nacional. Brasillia, 19986. 
BANCO MUNDIAL. A importância das finanças. Relatório sobre - Desenvolvimento Mundial, p.27-43, 1989.

BARROS, G.S.C.; ARAÚJO, P.F.C. A política de crédito rural no Brasil: Perspectivas para os anos 90. Piracicaba: CEPEA/FEALQ, 1991a. 17p. (Relatório de resultados, n.11).

BARROS, G.S.C.; ARAÚJO, P.E.C. Estimativas de custos bancários de transação do Crédito Rural no Brasil. Piracicaba: CEPEA/FEALQ, 1991b. 41p. (Relatório de resultados, n.7).

BOUMAN, F.J.A. Modalidades informales de ahorro y credito en paises de ingresos bajos: la experiencia de Sri Lanka. In: ADAMS, D.W.; GONZÁLEZ VEGA, C.; VON PISCHKE, J.D. Credito agricola $\mathbf{y}$ desarrollo rural: la nueva vision. Columbus: Ohio State University, 1987. p.281-298.

BOURNE, C.; GRAHAM, D.H. Problemas de las instituciones especializadas de crédito agropecuario. In: ADAMS, D.W.; GONZÁLEZ VEGA, C.; VON PISCHKE, J.D. Credito agricola Y desarrollo rural: lá nueva vision. Columbus: Ohio state University, 1987. p.57-72.

CENSO AGROPECUÁRIO - 1995/1996. http: \\WWW.ibge.gov.br. 1998.

CHRISTEN, R.P. Formal credit for informal borrowers: lessons from informal lenders. In: ADAMS, D.W.; FITCHETT, D.A. Informal finance in low-income countries, Colorado: Westview Press, 1992, p.281-292. 
CUEVAS, C.E. Transaction costs of financial intermediation in developing countries. Columbus: Ohio State University, 1988 .

CUEVAS, C.E.; GRAHAM, D.H. Costos de prestamos agricolas en Honduras. In: ADAMS, D.W.; GONZÁLEZ VEGA, C.; VON PISCHKE, J.D. Credito agricola $y$ desarrollo rural: Ia nueva vision. Columbus: Ohio State University, 1987. p. 183-191.

DATEY, C.D. The financial cost of agricultural credit: a case study of indian experience. World Bank staff working Paper, n.296, Oct. 1978 .

GETUBIG, I.P. et al. Overcoming poverty through credit the asian experience in replicating the Grameen Bank approach. Kuala Lumpur: Asian and Pacific Development Centre, 1993.

GONZÁLEZ VEGA, C. Credito agropecuario artificialmente barato: redistribucion al reves. In: ADAMS, D.W.; GONZÁLEZ VEGA, C.; VON PISCHKE, J.D. Credito agricola Y desarrollo rural: la nueva vision. Columbus: Ohio state University, 1987. p.125-139.

GONZÁLEZ VEGA, C.; GARITA, M.A.G. Costos de endeụdamiento, tasas de interes $y$ distribucion del credito en costa Rica. In: ADAMS, D.W.; GONZÁLEZ VEGA, C.; VON PISCHKE, J.D. Credito agricola $y$ desarrollo rural: la nueva vision. Columbus: Ohio State University, 1987. p.154164. 
GRAHAM, D.H.; FIRESTINE, R.E. Una agenda para la reforma de los mercados financieros rurales en los paises de ingresos bajos. In: ADAMS, D.W.; GONZÁLEZ VEGA, C.; VON PISCHKE, J.D. Credito agricola $\mathbf{Y}$ desarrollo rural: Ia nueva vision. Columbus: Ohio state University, 1987. p. $348-360$.

GUIDETTI, J.C.S.; ARAÚJO, P.F.C. Custos bancários de transação no crédito rural: revisão de literatura e aspectos metodológicos. Piracicaba: ESALQ/USP, 1994 a. $23 p$.

GUIDETTI, J.C.S.; ARAÚJO, P.E.C. Custos bancários de transação no crédito rural em agências de banco oficial. Piracicaba: ESALQ/USP, 1994b. 21p.

MEYER, R.L.; CUEVAS, C.E. Reducing the transaction costs of financial intermediation: theory and innovations. Columbus: Ohio State University, 1990.

NAKANO, Y. O crédito rural num contexto de modernização da economia brasileira. In: SEMINÁRIO NACIONAL: AS DIEÍCEIS OPÇÕES DO FINANCIAMENTO RURAL, Belo Horizonte, 1992. Separata dos Anais. Belo Horizonte, MG, 1992. p.1-18.

PESSÔA, A.S.M. Custos bancários de transação do crédito rural no Brasil. Piracicaba, 1996. 94p. Dissertação (Mestrado) - Escola Superior de Agricultura Luiz de Queiroz, Universidade de São Paulo. 
APÊNDICE 1: Agências incluídas na amostra do banco.

\section{REGIÃO CENTRO-OESTE}

MATO GROSSO DO SUL

Amambai

Angélica

Aquidauana

Aral Moreira

Bataguassu

Bela Vista

Bodoquena

Caarapó

Caarapo

Camapuã
Cassilandia
Deodápolis
Douradina
Eátima do SuI
Glória de Dourados
Iguatemi
Itaporã
Maracaju

MATO GROSSO

Alto Araguaia

Araputanga

Barra do Bugres

Barra do Garças
Anicuns
Itumbiara
Jataí
Itaúba

Jaciara

Jauru

Lucas do Rio Verde

\section{GOIÁs}

\author{
Mineiros \\ Porangatu \\ Quirinópolis

\section{DISTRITO FEDERAI} \\ Cto Brasilia
}

Rio Verde

São Miguel do Araguaia

Mirassol d'Oeste

Paranatinga

Sorriso

URB 24 de outubro 


\section{REGIÃO SUDESTE}

\section{SÃo PAULO}

\begin{tabular}{|c|c|c|}
\hline Altinópolis & Ibiúna & Pontal \\
\hline Araçatuba ' & Itai & Rancharia \\
\hline Araraquara & Itapetininga & Ribeírão Branco \\
\hline Assis & Itapira & Ribeirão Preto \\
\hline Avaré & Itápolis & São Carlos \\
\hline Barretos & Jundiai & São João da Boa Vista \\
\hline Bebedouro & Leme & São José da Bela Vista \\
\hline Birigui & Marília & São Paulo \\
\hline Bom Sucesso & Matão & Serrana \\
\hline Descalvado & Paraguaçu Paulista & Sertãozinho \\
\hline Dracena & Pedrinhas Paulista & Suzano \\
\hline Estiva & Pereira Barreto & Terra Roxa \\
\hline Garça & Piracicaba & Votuporanga \\
\hline \multirow[t]{2}{*}{ Ibitinga } & Pirassununga & \\
\hline & MINAS GERAIS & \\
\hline Araguari & Ituiutaba & Santa Juliana \\
\hline Araxá & Iturama & Santa Rita do Sapucai \\
\hline Bom Repouso & Juiz de Fora & São Francisco de Sales \\
\hline Indianópolis & Mercês & São Sebastião do Paraíso \\
\hline Ipuiúna & Nova Ponte & Uberlândia \\
\hline \multirow[t]{2}{*}{ Itinga } & Pouso Alegre & Varginha \\
\hline & ESPÍRITO SANTO & \\
\hline Colatina & Iinhares & Vila Velha \\
\hline
\end{tabular}




\section{REGIÃO SUT}

\section{PARANÁ}

\begin{tabular}{|c|c|c|}
\hline Aguaí & Foz do Iguaçu & Paraíso do Norte \\
\hline Altônia & Goioerê & Paranacity \\
\hline Andirá & Grandes Rios & Paranavaí \\
\hline Apucarana & Guarapuava & Pinhão \\
\hline Arapongas & Ibiporã & Pitanga \\
\hline Araucária & Iguaraçu & Ponta Grossa \\
\hline Assai & Ipiranga & Primeiro de Maio \\
\hline Bandeirantes & Irati & Quatiguá \\
\hline Barbosa Ferraz & Jacarezinho & Rolândia \\
\hline Cafelândia & Jataizinho & Rondon \\
\hline Cambará & Juranda & Santa Fé \\
\hline Cambé & Lapa & Santa Helena \\
\hline Cambira & Laranjeiras do Sul & Santa Isabel do Ivaí \\
\hline Candói & Mandaguaçu & Santa Mariana \\
\hline Cascavel & Marialva & Santo Antônio da Platina \\
\hline Cidade Gaúcha & Marilândia do Sul & Santo Antônio do Sudoeste \\
\hline Contenda & Mariluz & São João do Ivaí \\
\hline Cornélio Procópio & Maringá & São Jorge do Ivaí \\
\hline Coronel Vivida & Mercedes & Sertanópolis \\
\hline Cruzeiro do Oeste & Missal & Tibagi \\
\hline Curiúva & Nova Aurora & Toledo \\
\hline Faxinal & Nova Cantu & Umuarama \\
\hline Florestópolis & $\begin{array}{l}\text { Nova Londrina } \\
\text { Palmeira }\end{array}$ & Vera Cruz do Oeste \\
\hline
\end{tabular}




\section{RIO GRANDE DO SUL}

Bento Gonçalves

Carazinho

Caxias do Sul

Chapada

Cruz Alta

Erechim

Campo Erê

Chapecó
Frederico Westphalen Ronda Alta

Marau

Novo Hamburgo

Palmeira das Missões São Borja

Panambi

Passo Fundo

Porto Alegre

SANTA CATARINA

Forquilhinha

Mafra

Lages

Xanxerê
Santa Maria

Santana do Iivramento

Tramandaí

Uruguaiana

Vacaria 
APÊNDICE 2: Matrizes de correlação entre as variáveis dos modelos econométricos.

Modelo I

Matrizes de correlação

AMOSTRA TOTAL

$\begin{array}{ccccc} & \mathrm{Y}_{1} & \mathrm{X}_{1} & \mathrm{X}_{2} & \mathrm{X}_{3} \\ \mathrm{Y}_{1} & 1.00000 & 0.18239 & -0.24040 & 0.61556 \\ & 0.0 & 0.0089 & 0.0005 & 0.0001 \\ \mathrm{X}_{1} & 0.18239 & 1.00000 & 0.46057 & 0.53038 \\ & 0.0089 & 0.0 & 0.0001 & 0.0001 \\ \mathrm{X}_{2} & -0.24040 & 0.46057 & 1.00000 & 0.32969 \\ & 0.0005 & 0.0001 & 0.0 & 0.0001 \\ \mathrm{X}_{3} & 0.61556 & 0.53038 & 0.32969 & 1.00000 \\ & 0.0001 & 0.0001 & 0.0001 & 0.0\end{array}$

\section{CENTRO-OESTE}

$\begin{array}{llll}Y_{1} & X_{1} & X_{2} & X_{3}\end{array}$

\begin{tabular}{|c|c|c|c|c|}
\hline$Y_{I}$ & $\begin{array}{c}1.00000 \\
0.0\end{array}$ & $\begin{array}{c}0.14704 \\
0.3295\end{array}$ & $\begin{array}{c}-0.02885 \\
0.8491\end{array}$ & $\begin{array}{c}0.51251 \\
0.0003\end{array}$ \\
\hline$x_{1}$ & $\begin{array}{c}0.14704 \\
0.3295\end{array}$ & $\begin{array}{c}1.00000 \\
0.0\end{array}$ & $\begin{array}{c}0.48030 \\
0.0007\end{array}$ & $\begin{array}{c}0.46037 \\
0.0013\end{array}$ \\
\hline$x_{2}$ & $\begin{array}{c}-0.02885 \\
0.8491\end{array}$ & $\begin{array}{c}0.48030 \\
0.0007\end{array}$ & $\begin{array}{c}1.00000 \\
0.0\end{array}$ & $\begin{array}{c}0.51055 \\
0.0003\end{array}$ \\
\hline$x_{3}$ & $\begin{array}{c}0.51251 \\
0.0003\end{array}$ & $\begin{array}{c}0.46037 \\
0.0013\end{array}$ & $\begin{array}{c}0.51055 \\
0.0003\end{array}$ & $\begin{array}{c}1.00000 \\
0.0\end{array}$ \\
\hline
\end{tabular}


Modelo I

Matrizes de correlação

\section{SUDESTE}

$\begin{array}{llll}Y_{1} & X_{1} & X_{2} & X_{3}\end{array}$

\begin{tabular}{|c|c|c|c|c|}
\hline$Y_{1}$ & $\begin{array}{c}1.00000 \\
0.0\end{array}$ & $\begin{array}{c}0.14099 \\
0.2704\end{array}$ & $\begin{array}{c}-0.47898 \\
0.0001\end{array}$ & $\begin{array}{c}0.52147 \\
0.0001\end{array}$ \\
\hline$X_{I}$ & $\begin{array}{c}0.14099 \\
0.2704\end{array}$ & $\begin{array}{c}1.00000 \\
0.0\end{array}$ & $\begin{array}{c}0.49300 \\
0.0001\end{array}$ & $\begin{array}{c}0.59741 \\
0.0001\end{array}$ \\
\hline $\mathrm{x}_{2}$ & $\begin{array}{c}-0.47898 \\
0.0001\end{array}$ & $\begin{array}{c}0.49300 \\
0.0001\end{array}$ & $\begin{array}{c}1.00000 \\
0.0\end{array}$ & $\begin{array}{c}0.21013 \\
0.0983\end{array}$ \\
\hline$x_{3}$ & $\begin{array}{c}0.52147 \\
0.0001\end{array}$ & $\begin{array}{c}0.59741 \\
0.0001\end{array}$ & $\begin{array}{c}0.21013 \\
0.0983\end{array}$ & $\begin{array}{c}1.00000 \\
0.0\end{array}$ \\
\hline
\end{tabular}

SUL

$Y_{1} X_{1} \quad X_{2} \quad X_{3}$

$\begin{array}{ccccc}Y_{1} & 1.00000 & 0.20433 & -0.11073 & 0.72187 \\ & 0.0 & 0.0458 & 0.2828 & 0.0001\end{array}$

$\mathrm{X}_{1}$

0.20433

1.00000

0.47936

0.48657

0.0458

0.0

0.0001

0.0001

$\mathrm{X}_{2}$

$-0.11073$

0.47936

1.00000

0.36941

0.2828

0.0

0.0002

$\mathrm{X}_{3}$
0.72187
0.0001

0.48657

0.36941

1.00000

0.0001

0.0002

0.0 


\section{Modelo II}

\section{Matrizes de correlação}

\section{AMOSTRA TOTAL}

$\begin{array}{ccccc} & \mathrm{Y}_{2} & \mathrm{X}_{1} & \mathrm{X}_{2} & \mathrm{X}_{3} \\ \mathrm{Y}_{2} & 1.00000 & -0.51524 & -0.62193 & -0.74286 \\ & 0.0 & 0.0001 & 0.0001 & 0.0001 \\ \mathrm{X}_{1} & -0.51524 & 1.00000 & 0.46057 & 0.53038 \\ & 0.0001 & 0.0 & 0.0001 & 0.0001 \\ \mathrm{X}_{2} & -0.62193 & 0.46057 & 1.00000 & 0.32969 \\ & 0.0001 & 0.0001 & 0.0 & 0.0001 \\ \mathrm{X}_{3} & -0.74286 & 0.53038 & 0.32969 & 1.00000 \\ & 0.0001 & 0.0001 & 0.0001 & 0.0\end{array}$

\section{CENTRO-OESTE}

\begin{tabular}{|c|c|c|c|c|}
\hline & $\mathrm{Y}_{2}$ & $\mathrm{X}_{1}$ & $\mathrm{X}_{2}$ & $\mathrm{X}_{3}$ \\
\hline$Y_{2}$ & $\begin{array}{c}1.00000 \\
0.0\end{array}$ & $\begin{array}{c}-0.44483 \\
0.0020\end{array}$ & $\begin{array}{c}-0.61296 \\
0.0001\end{array}$ & $\begin{array}{c}-0.85655 \\
0.0001\end{array}$ \\
\hline $\mathrm{X}_{1}$ & $\begin{array}{c}-0.44483 \\
0.0020\end{array}$ & $\begin{array}{c}1.00000 \\
0.0\end{array}$ & $\begin{array}{c}0.48030 \\
0.0007\end{array}$ & $\begin{array}{c}0.46037 \\
0.0013\end{array}$ \\
\hline$X_{2}$ & $\begin{array}{c}-0.61296 \\
0.0001\end{array}$ & $\begin{array}{c}0.48030 \\
0.0007\end{array}$ & $\begin{array}{c}1.00000 \\
0.0\end{array}$ & $\begin{array}{c}0.51055 \\
0.0003\end{array}$ \\
\hline$X_{3}$ & $\begin{array}{c}-0.85655 \\
0.0001\end{array}$ & $\begin{array}{c}0.46037 \\
0.0013\end{array}$ & $\begin{array}{c}0.51055 \\
0.0003\end{array}$ & $\begin{array}{c}1.00000 \\
0.0\end{array}$ \\
\hline
\end{tabular}


Modelo II

Matrizes de correlação

\section{SUDESTE}

$\begin{array}{ccccc} & Y_{2} & X_{1} & X_{2} & X_{3} \\ Y_{2} & 1.00000 & -0.59082 & -0.59592 & -0.78035 \\ & 0.0 & 0.0001 & 0.0001 & 0.0001 \\ X_{1} & -0.59082 & 1.00000 & 0.49300 & 0.59741 \\ & 0.0001 & 0.0 & 0.0001 & 0.0001 \\ X_{2} & -0.59592 & 0.49300 & 1.00000 & 0.21013 \\ & 0.0001 & 0.0001 & 0.0 & 0.0983 \\ X_{3} & -0.78035 & 0.59741 & 0.21013 & 1.00000 \\ & 0.0001 & 0.0001 & 0.0983 & 0.0\end{array}$

SUL

$Y_{2}$

$Y_{2}$

$\mathrm{X}_{1}$

$\mathrm{X}_{2}$

$\mathrm{x}_{3}$
1.00000

0.0

$-0.47915$

0.0001

$-0.65367$

0.0001

$-0.65384$

0.0001
$X_{1}$

$-0.47915$

1.00000

0.0

0.47936

0.0001

0.48657

0.0001
$\mathrm{X}_{2}$

$-0.65367$

0.0001

0.47936

0.0001

1.00000

0.0

0.36941

0.0002 $x_{3}$

$-0.65384$

0.0001

0.48657

0.0001

0.36941

0.0002

1.00000

0.0 